School of Finance

University of St.Gallen

CREDIT BOOMS AND BUSTS IN EMERGING MARKETS: THE ROLE OF BANK GOVERNANCE AND RISK MANAGEMENT

Alin ANDRIES

MARTIN BROWN

WORKING PAPERS ON FINANCE No. 2014/14

SWISS INSTITUTE OF BANKING AND FINANCE (S/BF - HSG)

SEPTEMBER 2014 


\title{
CREDIT BOOMS AND BUSTS IN EMERGING MARKETS: THE ROLE OF BANK GOVERNANCE AND RISK MANAGEMENT
}

\author{
Alin Marius ANDRIES ${ }^{*}$ and Martin BROWN B $^{\dagger}$
}

\begin{abstract}
This paper investigates to what extent risk management and corporate governance mitigate the involvement of banks in credit boom and bust cycles. Using a unique, handcollected dataset on 156 banks from Central and Eastern Europe during 2005-2012, we assess whether banks with stronger risk management and corporate governance display more moderate credit growth in the pre-crisis credit boom as well as a smaller credit contraction and fewer credit losses in the crisis period. With respect to bank governance we document that a higher share of financial experts on the supervisory board is associated with more rapid credit growth in the pre-crisis period and a larger contraction of credit in the crisis period, but not with larger credit losses. With respect to risk management we document that a strong risk committee is associated with more moderate pre-crisis credit growth but not with fewer credit losses in the crisis. We find no evidence of an organizational learning process among crisishit banks: those banks with the largest credit losses during the crisis are least likely to improve their risk management in the aftermath of the crisis.
\end{abstract}

JEL Classification: G21, G32, P34.

Keywords: Credit boom and busts, corporate governance, risk management

\footnotetext{
* Corresponding author: Alexandru Ioan Cuza University of Iasi, Romania (email: alin.andries@uaic.ro)

† University of St. Gallen, Switzerland (email: martin.brown@unisg.ch)

We thank Andrew Ellul, Ralph de Haas, Karolin Kirschenmann and Razvan Vlahu as well as participants at the 2014 International Risk Management Conference in Warsaw for helpful comments. This paper was completed while Andries was a visiting researcher at the University of St. Gallen. Financial Support from the Swiss Government under the SCIEX programme is gratefully acknowledged.
} 


\section{Introduction}

Over the past decade, the banking sectors of Central and Eastern European (CEE) have experienced an extraordinary credit boom and bust cycle. In the period prior to the financial crisis (2001-2008) annual growth of private credit averaged 38.57\% with a peak of 52.14\% in 2007. The credit boom in Eastern Europe far exceeded that in other emerging market regions (see Figure 1a), but also outpaced credit growth in well-documented boom countries such as Spain. The credit boom in Eastern Europe ended abruptly with the financial crisis of 2008, and has left a legacy of credit losses in the region. Non-performing loans in the CEE region increased to an average of 11 percent (end-2011) from just above 3 percent in 2007 (see Figure 1b). Completing the picture of a classic credit boom and bust cycle, nonperforming loans materialized most in those countries where the pre-crisis credit boom was the most extreme (see Figure 1c).

\section{Figure 1 here}

In this paper, we examine whether risk management and corporate governance within banks mitigated their involvement in the recent credit boom and bust cycle in Central and Eastern Europe. We first analyze whether banks with better risk management and corporate governance had more moderate credit growth during the pre-crises period (2005-2007) and a smaller contraction of credit in the crisis period (2009-2012). We then examine whether banks with better risk management and corporate governance had lower credit losses during the crisis period (2009-2012). Finally, we examine whether banks that experienced high credit losses during the crisis improve risk management and corporate governance more than banks that experienced low credit losses.

Our analysis is based on a unique dataset providing annual information on corporate governance, risk management and credit activity for 156 individual banks (39 domestic and 117 foreign banks), from 17 countries of Central and Eastern Europe over the period 20052012. We hand-collect information on the risk-management structure and the composition of the supervisory board for each bank from the banks' annual reports, financial statements, capital adequacy and risk management reports and websites. We merge our hand-collected dataset on risk management and corporate governance with annual financial indicators extracted for each bank from Bankscope as well as with country-level regulation and supervision indicators for each country from the World Bank. 
With respect to risk management our results document that the existence of a risk committee, i.e. a dedicated committee solely charged with monitoring and managing the risk management efforts within the bank, in particular, is associated with more moderate credit growth during the pre-crisis credit boom and a smaller contraction of credit in the crisis. That said risk committees are associated with larger rather than smaller credit losses in the crisis.

With respect to bank governance our results document that more financial experts on the supervisory board of a bank are associated with more rapid pre-crisis credit growth and a larger contraction of credit in the crisis. The latter finding confirms the results obtained by Minton et al. (2014) and are consistent with the idea that a more financially knowledgeable board encourages bank management to increase its risk-taking. However, we do not find that the share of financial experts on the board is associated with larger credit losses in the crisis. Thus while expert board members seem to push credit expansion, they also seem to help contain credit risk. We further document that a higher share of foreign members in supervisory boards is associated with fewer non-performing loans, especially in countries with weak regulatory frameworks.

Finally, in line with Fahlenbrach et al. (2012), we show that there is no evidence of a particular learning process by crisis-hit banks: banks that experience high credit losses during the crisis improve their risk management less than banks that experience low credit losses.

Our results primarily contribute to the recent literature on corporate governance and bank risk-taking. The failure of various governance mechanisms has often been cited among the key causes of the crisis (De Haan and Vlahu, 2013). Beltratti and Stulz (2012) argue that poor bank governance was a major cause of the crisis and find that banks with more shareholder-friendly boards performed significantly worse during the crisis than other banks, were more risky before the crisis, and reduced loans more during the crisis. Kirkpatrick (2009) concludes that the financial crisis can, to an important extent, be attributed to failures and weaknesses in corporate governance arrangements. Ellul and Yerramilli (2013) find that banks with stronger risk-management functions in place before the onset of the financial crisis had lower tail risk, a smaller fraction of nonperforming loans, better operating performance, and higher annual returns during the crisis years, 2007 and 2008. Their results suggest that a strong and independent risk-management function can curtail tail-risk exposures at banks. Aebi et al. (2012) investigate whether risk management-related corporate governance mechanisms are associated with better bank performance during the financial crisis of 2007/2008. Their results indicate that banks, in which the Chief Risk Officer (CRO) directly reports to the board of directors, exhibit significantly higher (i.e., less negative) stock 
returns and profitability during the crisis. Erkens et al. (2012) investigate the influence of corporate governance on financial firms' performance during the 2007-2008 financial crisis and find that firms with more independent boards and higher institutional ownership experienced worse stock returns during the crisis period. Minton et al. (2014) show that financial expertise among independent directors of U.S. banks is positively associated with balance-sheet and market-based measures of risk in the run-up to the 2007-2008 financial crisis. Overall, existing empirical research does not seem to support the proposition that better governance in banks leads to less risk before the crisis or better performance during the crisis (Stulz, 2014). Our results complement these findings by documenting how risk management and corporate governance affect banks involvement in credit boom and bust cycles in an emerging market context.

We also contribute to the literature that examines the relationship between regulation and banks' risk taking. Regulation could be considered as a complementary, external governance force, which may be particularly relevant for banks with weak internal governance. Previous studies suggest that bank risk-taking responds to changes in domestic regulation and supervision (Barth et al., 2004; Buch and DeLong, 2008). When regulatory constraints are removed, the outcome may critically depend on the interaction between corporate governance and firm behavior, particularly if behavior is not primarily driven by value maximization and if the regulatory constraints have been designed to inhibit risk-taking (Illueca et al., 2014). Laeven and Levine (2009) show that the relationship between bank risk and capital regulations, deposit insurance policies, and restrictions on bank activities, depends critically on each bank's ownership structure, such that the actual sign of the marginal effect of regulation on risk varies with ownership concentration. Their findings show that the same regulation has different effects on bank risk-taking, depending upon the bank's corporate governance structure. Beltratti and Stulz (2012) show that the differences in banking regulations across countries are generally uncorrelated with the performance of banks during the crisis, except that large banks from countries with more restrictions on bank activities performed better and decreased loans less. Ongena et al. (2013) find that foreign banks which have lower barriers to entry, tighter restrictions on bank activities, and higher minimum capital requirements in their home markets are display lower bank-lending standards abroad. Our findings complement this literature by documenting that host country regulation hardly seems to influence the relation between bank governance and bank involvement in credit boom and bust cycles. 


\section{Data}

The dataset used in our research is composed of annual data for 156 commercial banks operating in the 17 countries from Central and Eastern Europe. ${ }^{3}$ As a starting point for our sample we consider all commercial banks from Central and Eastern European countries available in the BankScope database in $2012 .{ }^{4}$ We collect the data for a total of 462 active banks from 17 CEE countries for the 2005-2012 period. Out of the 462 banks, only 260 banks have detailed information for at least 5 years. Following Claessens and van Horen (2012), we account for mergers and acquisitions, and entry and exit during the analyzed period.

We hand-collect annual information on risk management and corporate governance at each bank from the banks' annual reports, financial statements websites. Complete data are available for 156 banks, of which 39 are domestic banks and 117 are foreign banks. ${ }^{5}$ Across CEE countries, foreign ownership in the banking sector has grown dramatically in the recent decade, and by 2008, foreign banks controlled around $80 \%$ of the assets in the region's banking industry, and in countries such as Estonia and Slovak Republic more than $95 \%$. Our sample accounts for $82 \%$ of the total assets of the CEE banking systems in 2012. The structure of our dataset for 2008, in terms of host and home countries, is presented in Figure 2. The number of banks per country range from 5 in Albania and Lithuania to 12 in Poland and Romania. In terms of home countries, most foreign banks in Central and Eastern European countries are from Austria (29), Italy (20) and Greece (13).

\section{Figure 2 here}

\subsection{Risk management and corporate governance}

Our first set of indicators assesses the quality of risk management within a bank. The first indicator is the dummy variable CRO Present that identifies whether a Chief Risk

\footnotetext{
${ }^{3}$ Albania, Bosnia and Herzegovina, Bulgaria, Croatia, Czech Republic, Estonia, Hungary, Latvia, Lithuania, Macedonia, Montenegro, Poland, Romania, Serbia, Slovakia, Slovenia and Ukraine.

${ }^{4}$ One concern related to the empirical analysis is the potential heterogeneity among different financial institutions. The impact of the financial crisis arguably might differ across commercial banks, cooperative banks, investment banks and real estate and mortgage banks. To make sure that there is consistency across the sample, we restricted the investigation to the commercial banking sector, which comprises one of the largest segments of depository institutions in Europe (Chortareas et al., 2013).

${ }^{5}$ We classify banks into foreign and domestic banks depending on whether $50 \%$ or more of banks' shares are owned by foreigners or by central, local governments or domestic private actors (Claessens and van Horen, 2014).
} 
Officer (CRO) ${ }^{6}$ responsible for bank-wide risk management is present within the bank. Keys et al. (2009) show that a stronger risk-management department inside the bank partially alleviates the moral hazard problem. Also, policy makers stress that banks should appoint a totally independent CRO responsible for the risk-management function across the entire organization, and for coordinating the activities of other units relating to the institution's riskmanagement framework (Walker 2009; CEBS, 2010). The second indicator, CRO Executive, identifies whether the CRO is an executive officer of the bank. If the CRO is a member of the managing board, his influence and power are expected to be larger as compared to a CRO who is situated on the third management level (Aebi et al., 2012). We would expect that having the CRO as a member of a managing board indicates, in general, stronger risk management.

The indicator Risk committee is equal to 1 if the bank has a dedicated committee solely charged with monitoring and managing risk-management efforts within the bank. According to Walker (2009), risk governance requires a dedicated standalone risk committee, apart from the Audit Committee or the Asset and Liability Management Committee; this standalone risk committee focuses on the current and forward-looking aspects of risk exposure. Landier et al. (2009) shows that a firm that has a CRO or a centralized riskmanagement committee at the board-level may make the firm less prone to taking risks that are detrimental to long-term firm value. Thus, we assume that having a CRO and a risk committee indicates better risk management. The indicator Reports to board identifies whether the key management-level risk committee reports directly to the bank's board of directors instead of to the CEO. The Basel Committee on Banking Supervision (BCBS, 2010) considers that the risk committee, responsible for advising the board on the bank's overall current and future risk tolerance/appetite and strategy, and for overseeing senior management's implementation of that strategy, should be at a board-level.

Based on our four indicators of risk management, we create a composite Risk management index as an unweighted average index that takes values between 0 and 1 , with 1 representing tight risk management. Table 1 Panel A documents only small differences in the quality of risk management between domestic and foreign banks: foreign banks have slightly higher levels of the Risk management index than domestic banks before the crisis $(0.35$ foreign banks / 0.33 domestic banks). However, the similarities in the composite risk

\footnotetext{
${ }^{6}$ The banks use the Chief Risk Officer or an equivalent title such as: Deputy CEO -Risk, Executive Vicepresident Risk; Chief Strategy and Risk Officer, Chief Credit and Risk Officer, Chief Lending and Risk Officer; Global Risk Executive, Director of Risk Management, Chief Risk Manager; Vice-president - Risk Division; Executive Vice-president Risk; or Risk Management Officer.
} 
management index of foreign and domestic banks masks larger countervailing differences with respect to risk committees and chief risk officers: On the one hand domestic banks are more likely to have a Risk committee (23\% vs. $18 \%$ ) and a risk committee that reports to the board (18\% vs. $12 \%)$ than foreign banks. On the other hand foreign banks are more likely to have a CRO present (85\% vs. $79 \%$ ) and a CRO executive (24\% vs. 13\%).

The quality of risk management as measured by our Risk management index differs strong across countries before the crisis. As shown by Figure 3a shows, banks in Montenegro display the lowest level of risk management (0.16) while banks in Macedonia (0.48) display the highest level. The variation in risk management across countries is not driven entirely by difference in the composition of the banking sector. Figure $3 b$ shows that even within a given international banking group there is substantial variation in risk management across countries.

\section{Table 1 here}

Figure 3 here

Our second set of indicators assesses the structure of corporate governance as measured by the size and structure of the supervisory board. Hereby we follow existing studies in measuring the number of board members as well as their financial expertise and independence. In addition and important in our context, we account for the share of foreign members on the board.

The indicator Board size is measured as the natural logarithm of the number of directors on a bank's board. ${ }^{7}$ We measure Board expertise by the share of expert members on the board. Similar to Güner et al. (2008) and Minton et al. (2014), we classify a member of the supervisory board as an expert if he or she (i) has worked within a banking institution, (ii) currently works at a non-bank financial institution, (iii) has a finance-related role within a non-financial firm (e.g., CFO, accountant, treasurer, or VP finance), (iv) has a finance-related role within an academic institution (e.g., professor in finance, accounting, economics, business or financial law), or (v) has an economic studies background. Previous studies show that banks with more financial experts on their boards limit their risk exposure before the crisis and exhibit better stock-return performance during the crisis (Fernandes and Fich, 2013).

\footnotetext{
${ }^{7}$ Adams and Mehran (2012) find that board size is positively related to performance and De Andres and Vallelado (2008) find an inverted U-shaped relationship between board size and performance.
} 
The indicator Board independence measures the share of independent outside directors on the supervisory board. Independent members are generally supposed to be in a position to exercise a more effective advising and monitoring role on managerial behavior, and this can materialize as a positive contribution in terms of firm performance (Cornett et al., 2010). ${ }^{8}$ Following Aebi et al. (2012), we define independent members of the board as members without any relationship with the company except for their board seat.

The indicator Board foreign captures the share of foreign members on the supervisory board. Most foreign bank subsidiaries in our sample have boards that are dominated by executives from the parent bank, with the local chairperson being the chief executive officer or deputy chief executive officer of the parent bank. ${ }^{9}$ In the case of domestic banks, most foreign members are representatives of strategic investors, e.g., European Bank for Reconstruction and Development. This implies that across our sample of banks Board Foreign is positively correlated with Board Expertise (0.45) and negatively correlated with Board independence $(-0.28){ }^{10}$

Based on our four indicators of board size and structure we calculate a Supervisory board index as an unweighted average index which takes values between 0 and 1 . In order to calculate the index, we first normalize the variable Board size. As can be seen in Figure 3b and Table 1 Panel A, there is substantial variation of the Supervisory board index across banks prior to the crisis. Unsurprisingly, the structure of the supervisory board differs strongly between foreign and domestic banks: The share of expert members (92\% vs. 78\%) and foreign members (70\% vs. 17\%) is higher for foreign banks. By contrast, the share of independent members on supervisory boards is lower for foreign banks than domestic banks (15\% vs. 25\%). We also observe that foreign banks have, on average, slightly larger supervisory boards than domestic banks.

Figure 3 shows that corporate governance differs strong across countries, with banks in Estonia displaying the lowest average level of governance (0.34) while banks in Serbia display the highest level (0.70) prior to the crisis. Figure 3d shows that even within a given

\footnotetext{
${ }^{8}$ A potential disadvantage of independent members of a supervisory board is that they may lack relevant firmspecific information (Adams and Ferreira, 2007), which is likely to be especially problematic for small growth firms. It is less clear what the relationship between board independence and bank performance and risk-taking should be (see e.g. Pathan, 2009; Cornett et al., 2010; Adams and Mehran, 2012; Berger et al., 2013; Minton et al., 2014).

${ }^{9}$ Allen et al. (2013) stress that in the case of these banks the parent bank board members are the only ones with the knowledge and access to information to monitor the bank's risk. In addition, subsidiary boards are expected to benefit from the presence of board members with regional expertise.

${ }^{10}$ See Appendix 3 for a full correlation matrix of risk management and corporate governance variables.
} 
international banking group there is substantial variation in corporate governance across countries.

Figure 3e shows that the Corporate governance index and Risk Management index are largely uncorrelated across banks prior to the crisis. Thus corporate governance and risk management do not seem to be used as substitutes in terms of containing the risk exposure of banks. This finding is also confirmed in Appendix 3 where we present a correlation matrix for our individual indicators of governance and risk management.

\subsection{Credit Growth and Credit Losses}

We focus our attention on the involvement of banks in the credit boom and bust cycle as measured by (i) rapid pre-crisis credit growth, (ii) a strong drop in credit growth from the pre-crisis to crisis period and (iii) a high non-performing loans ratio during the crisis. From BankScope, we extract two indicators: annual growth of gross loan as a measure of Credit growth and NPLs to gross loan ratio as a measure of Credit losses. Previous studies show that rapid credit growth is an early indicator of build-up of credit risk (Maechler et al., 2010). Results by Foos et al. (2010) suggest that loan growth represents an important driver of the riskiness of banks, and Dell'Ariccia et al. (2012) present evidence that fast credit growth can be linked to a decline in lending standards and problems in loan performance. Table 1 Panel A shows that the average annual rate of credit growth in the pre-crisis period is $49 \% .{ }^{11}$ The variation of pre-crisis credit growth across our sample is substantial with annual growth rates varying from $20 \%$ to $195 \%$. We observe that the average credit growth pre-crisis of domestic banks (53.29\%) is slightly higher than foreign banks (48.08\%). This result is in line with Berger et al. (2014) who find that foreign banks are more conservative than domestic banks, and that during normal times foreign banks tend to lend to safer borrowers with lower interest rate spreads and to avoid borrowers with junk ratings.

During the crisis period (2009-2012), annual credit growth dropped to an average level of $5.8 \%$, again with lower growth rates in the case of foreign banks $(3.9 \%)$ than domestic banks (10.9\%). Figure 4a documents that across our sample credit growth during the crisis period is hardly correlated with pre-crisis credit growth. This implies that - as documented by Figure $4 \mathrm{~b}$ - the strongest drop in credit growth from the pre-crisis to the crisis period was recorded by banks with the fastest credit growth before crisis.

\footnotetext{
${ }^{11} 49.48 \%$ represents the unweighted average of gross loan annual growth for all banks from our sample during the pre-crisis period. The average of gross loan annual growth weighted by total assets of banks during the precrisis period is $36.29 \%$.
} 


\section{Figure 4 here}

Regarding NPLs during the crisis, the average bank had a non-performing loan ratio of 14.3\% over the 2009-2012 period. The average level of NPLs for domestic banks (18.3\%) is substantially higher than for foreign banks (12.8). Figure 4c documents a strong correlation (0.39) between pre-crisis credit growth and NPLs during crisis: banks that display faster credit growth before the crisis report a higher level of NPLs during the crisis.

\subsection{Bank regulation and supervision}

We examine whether the relationship between corporate governance, riskmanagement indicators and bank risk-taking varies with of the quality of bank regulation in the host country. ${ }^{12}$ To this end we compile a Regulatory Index measured as a normalized unweighted average index of three regulation and supervision indicators (Restrictions on banking activities index, Capital regulatory index, and Official supervisory power index) that are constructed using the data from the survey of bank regulations conducted by the World Bank. The first variable, Restrictions on banking activities index, is a composite index of regulatory restrictions on bank activities from Barth et al. (2004). It measures the degree to which banks face regulatory restrictions on their activities in securities markets, insurance, real estate, and ownership of shares in nonfinancial firms; higher values indicate greater restrictions. The second variable, Capital regulatory index, is an index of regulatory oversight of bank capital, including indicators for whether the sources of funds that count as regulatory capital can include assets other than cash and government securities, and whether authorities verify the source of capital (Beltratti and Stulz, 2012). The third variable, Official supervisory power, is an index that expresses the power of the commercial bank supervisory agency to undertake actions such as demanding information, forcing a bank to change the internal organizational structure and obliging it to suspend dividend payments, and intervening in the bank's management.

\footnotetext{
${ }^{12}$ Previous studies showed that the relationship between bank risk and corporate governance vary with national regulations (e.g., Shleifer and Vishny, 1997; John et al., 2008; Laeven and Levine, 2009). However, previous studies show little consensus as to what constitutes good regulation and supervision, or how specific regulations influence the performance of the banking sector (see, e.g., Barth et al., 2004; Demirguc-Kunt et al., 2008). Empirical evidence concerning the impact of regulations on bank performance and risk-taking appears mixed (see, e.g., Barth et al., 2004; Beck et al., 2006; Delis and Staikouras, 2011; Demirguc-Kunt et al., 2004).
} 
We construct the Regulatory Index for all 17 host countries. We define a host country as a country with a lax regulation if the value of Regulatory index for that country is lower than the median value of Regulatory index for the entire sample of countries. The structure of our dataset, in terms of host-countries' regulation and supervision framework, is presented in Figure 5. We observe that the highest levels of Regulatory index, meaning tight regulation, are recorded in Slovenia and Hungary. The countries with the lowest level of Regulatory index are Serbia and Montenegro. Table 1 Panel B shows that the Regulatory index of the host countries included in our sample range from 0.43 to 0.75 with a mean index score of 0.59 .

\section{Figure 5 here}

\subsection{Bank-level control variables}

Prior studies suggest a significant relationship between bank size, bank businessmodels and bank risk taking (Altunbas et al., 2011). To control for differences in size and business models across our sample, we employ following bank-level control variables: 1) Bank size measures (log) total assets of the bank in the pre-crisis period; 2) as in Beltratti and Stulz (2012) we use the Loans to total assets ratio captures the banks' investment strategy; 3) following Demirguc-Kunt et al. (2013) we use Capital structure (Equity/Total assets) defined as regulatory capital divided by total assets. We winsorize the bank-level explanatory variables at the $1 \%$ and $99 \%$ levels.

From Table 1 Panel A we observe substantial differences in terms of Bank size across our sample: while the average volume of bank assets is 4.8 billion EUR, this ranges from 40 million USD to 38.1 billion across banks. Regarding asset structure, we observe that Loan to total assets ratio before the crisis ranges between $22 \%$ and $89 \%$, with an average level of 59\%. Foreign banks are on average larger than domestic banks (4.8 vs. 3.5 billion EUR), but display a similar loan to total asset ratio (60\% vs. 56\%). Similar to Gropp and Heider (2010), we observe that there is a large variation in banks' capital ratios across CEE banking systems. The ratio of book equity to book assets before crisis ranges from $3.43 \%$ to $35.72 \%$, \%, with an average level of $11.54 \%$. Domestic banks are on average better capitalized than foreign banks $(13.77 \%$ vs. $10.71 \%)$

\section{Results}




\subsection{Pre-crisis credit growth}

We first analyze whether banks with better risk management and corporate governance are characterized by more moderate credit growth during the pre-crises credit boom. Table 2 presents results of a multivariate regression analysis that examines the relationship between pre-crisis Credit growth, risk management and corporate governance. The dependent variable in the OLS regressions is the average annual credit growth rate over the 2005-2007 period. We estimate 11 models using our full sample of banks. All models include host-country fixed effects and allow for clustering of standard errors at the country level.

\section{Table 2 here}

The Table 2 results show that the existence of a Risk committee is associated with 9.2 percentage points lower pre-crisis Credit growth (Model 3). If the Risk committee reports to board pre-crisis Credit growth is a further 7.9 percentage points lower (Model 4). By contrast, the existence and hierarchical position of the chief risk officer is positively, but not significantly correlated with pre-crisis credit growth (Models $1 \& 2$ ). As a result of this latter finding, the composite Risk management index ${ }^{13}$ is not significantly correlated with pre-crisis credit growth (Model 9).

With respect to the structure of the supervisory board the estimates obtained for Model 5 suggests that (controlling for bank size) the size of the supervisory board is not associated with pre-crisis credit growth. Model 6 in Table 2 shows that more expert members on the supervisory board are associated with more rapid Credit growth during the pre-crisis period: A one-standard-deviation increase in Board expertise levels during the pre-crisis period is associated with an increase of 6.12 percentage points in pre-crisis Credit growth, compared to a mean pre-crisis Credit growth of about $49.4 \%$. This result is in line with results obtained by Minton et al. (2014) and is consistent with financial experts who act in the interest of shareholders, as shareholders benefit from more risk-taking given that their cost of capital does not reflect the riskiness of their assets. Also, this result is consistent with a more financially knowledgeable board that has a better understanding of the lending business and that potentially encourages bank management to increase its risk-taking. While board

\footnotetext{
${ }^{13}$ Although we do not reproduce the results, we use as robustness check other different methods to construct indices, additive indices (e.g., Beltratti and Stulz, 2012) or principal component analysis (e.g., Ellul and Yerramilli, 2013), and the results are similar.
} 
expertise seems to influence pre-crisis credit growth this does not seem to be the case for the share of independent board members (Model 7) or foreign board members (Model 8). Reflecting the varying results in Models 5-8, the composite Supervisory board index is not significantly associated with pre-crisis credit growth (Model 10).

The results obtained in Models 3, 4 and 6 of Table 2 show that, controlling for bank size, banks with stronger risk committees and fewer financial experts on their supervisory board are characterized by more moderate credit growth in the pre-crisis boom period. Within our sample, domestic banks have both stronger risk committees and fewer financial experts on their boards (see Table 1). However, these differences in risk management and board structure do not translate into a significant difference in pre-crisis credit growth between foreign and domestic banks (see Model 11). The lower pre-crisis credit growth for foreign banks (5.21 percentage points) displayed in Table 1 is partly attributable to differences in bank size between foreign and domestic banks. All models in Table 2 report a significant and large negative correlation between bank size and pre-crisis credit growth.

\subsection{Credit growth during the crisis}

Concerns about a dramatic credit crunch in the Central and Eastern European countries led to a concerted effort by regulators and multilateral institutions to preserve minimum levels of lending (De Haas et al., 2014). The crisis triggered an increasing research effort to disentangle the factors that drove the fall of credit growth in most countries from this region (see e.g., Feyen et al., 2014; Choi et al., 2013). In this section, we explore the role of risk management and corporate governance on banks credit activity during the crisis. In order to assess the impact of risk management and corporate governance on credit provision during the crisis we first examine the drop in credit growth from the pre-crisis period to the crisis period (Table 3). We then examine the level of credit growth in the crisis period (Table 4).

\section{Table 3 here}

Tables 3 presents the results of a multivariate regression analysis that examines the relationship between Credit drop, bank governance and risk management. The dependent variable Credit drop is the change in the credit growth rate from the pre-crisis period (20052007) to the crisis period (2009-2012). The results for Models 3-4 reveal that the coefficients of Risk committee and Risk committee reports to board are negative and of similar magnitude 
(but less precisely estimated) to the results obtained in Table 2 for pre-crisis credit growth. Also, we find that having more expert members on the supervisory board has a positive and statistically significant impact on Credit drop (Model 6). The magnitude of this effect is again similar to that obtained in Table 2 for pre-crisis credit growth. These results are not surprising as Figure 4b documents that those banks which boasted the fastest credit growth during the crisis were also responsible for the sharpest drop in credit growth once the crisis hit.

\section{Table 4 here}

Which banks do display the highest credit growth in the crisis? Figure 4a shows that the rate of credit growth during the crisis period varied substantially across our sample of banks and is almost unrelated to the rate of credit growth prior to the crisis. In Table 4 we examine to what extent bank governance and risk management are associated with in-crisis credit growth. The dependent variable in the OLS regressions is average annual credit growth over the 2009-2012 period.

With respect to risk management we find that the position of the chief risk officer is associated with Credit growth in the crisis. Banks with a CRO executive have, on average, an annual rate of Credit growth during the crisis which is 3 percentage points higher than banks without CRO executive. By comparison the average rate of credit growth during the crisis period is $5.8 \%$.

In terms of board characteristics, we find that contrary to the pre-crisis period, banks with a larger Board size do not grow faster during the crisis (Model 5). The association is again both economically and statistically significant: a one-standard-deviation increase in Board size during the pre-crisis period is associated with a decrease of $3.2 \%$ in Credit growth during the crisis.

Model (8) in Table 4 reports a large and negative, but not significant coefficient for Board foreign. Similarly, Model 11 reports a large and negative coefficient (again imprecisely estimated) for Foreign ownership. These results are in line with existing evidence by De Haas et al. (2014) documenting that in Emerging Europe foreign banks did curtail lending more strongly than domestic banks from 2009 onwards. Besides ownership structure, differences in the average size of foreign vs. domestic banks also contribute to lower credit growth observed for foreign banks: the estimated coefficient for Size of bank is negative and statistically significant in all models of Table 4. Interestingly, the magnitude of 
the coefficient of Size of bank is similar to that reported for the pre-crisis period in Table 2. This finding suggests that large banks were not just more prudent in the pre-crisis credit boom, but were equally reluctant to expand lending during the crisis.

\subsection{Credit losses during the crisis}

In the previous sections we showed that good risk management (e.g. a strong risk committee) is associated with a more moderate pre-crisis credit growth, while more financial experts on the board are associated with a stronger involvement in the boom-bust cycle. In this section we examine to what extent differences in risk management and governance also affect realized credit losses during the crisis. Table 5 reports our multivariate regression analysis which relates risk management and corporate governance during the pre-crisis period to Credit losses in the crisis period. The dependent variable is the average NPLs ratio over the 2009-2012 period. ${ }^{14}$ All explanatory variables are measured as the average over the 2005-2007 period. Again, all estimated models include host-country fixed effects and allow for clustering of standard errors at the country level.

\section{Table 5 here}

With respect to risk management we find that banks with a strong risk committee (Risk committee reports to board) display higher levels of NPLs during the crisis (Model 4). This finding is somewhat surprising as the previous results suggest that these banks are characterized by a more stable credit growth during the boom-bust cycle. One explanation for this finding is that the presence of a risk committee that reports to the board forces management to recognize (rather than evergreen) credit losses during the crisis. An alternative explanation is that this result is driven by differences in the loan structure between banks which have a strong risk committee and banks that don't. Banks with strong risk management committees may require these because they have a larger relative credit exposure to the corporate sector (as opposed to the household sector). Existing evidence for Emerging Europe suggests that the retail credit segment experienced stronger pre-crisis credit growth than the corporate lending segment (Brown and De Haas, 2012). At the same time corporate borrowers are more likely to be directly hit by the economic crisis which spread to

\footnotetext{
${ }^{14}$ Although we do not report the results, we investigate the impact of risk management and corporate governance during the pre-crisis period to bank risk quantified using Loan Loss Provisions/Total Loans ratio during the crisis period and the results are similar to the results obtained using NPLs.
} 
Eastern Europe from 2009 onwards. Unfortunately, we could obtain information on the credit portfolio structure for only 65 of the 156 banks in our sample. ${ }^{15}$ The data for these banks confirms our conjecture that banks with a stronger focus on corporate credit are less involved in the credit-boom and bust cycle, but do experience higher credit losses during the crisis. Thus the observed correlation between risk management and credit losses may well be driven by omitted information on credit portfolio structure.

With respect to the supervisory board, we do find that a larger share of foreign board members is associated with lower Credit losses during the crisis (Model 8). In terms of economic effects, a one-standard-deviation increase in Board foreign is associated with a 2.15\% drop in the NPLs level during the crisis, relative to the NPLs mean during the crisis this is about $14.3 \%$.

\subsection{The role of the regulatory framework}

The impact of the risk management and corporate governance on bank risk-taking may arguably differ across countries with a different level and quality of regulation framework. Appendix 4 therefore present a series of regression analyses in which we examine whether the regulatory framework in the host-country affects the relation between bank governance and risk management and bank involvement in the credit boom and bust cycle. Following Laeven and Levine (2009), we include the interaction term of corporate governance and risk-management indicators with an indicator for the strength of the regulatory framework. We define each country as a country with a lax regulation, if the value of Regulatory index for that country is lower than the median value of Regulatory index for entire sample of countries. Using this strategy, we determine the quality of regulatory framework for all host countries. ${ }^{16}$

The Appendix 4a and 4b results suggest that the relations between pre-crisis Credit growth and the Credit drop in the crisis on the one hand and corporate governance and riskmanagement on the other hand vary somewhat with the regulatory framework in host countries. The estimated coefficients of the interaction terms with lax regulation are, however, in general not statistically significant. A notable exception is the large and significant positive coefficient estimated for the interaction term CRO executive * Lax

\footnotetext{
${ }^{15}$ We thank the EBRD for sharing this information from their BEPS survey on a confidential basis.

${ }^{16}$ Although we do not reproduce the results, we investigate the the direct and interactive associations among credit growth, risk management and corporate governance, and regulatory framework during pre-crisis period using the Official Supervisory Power index instead of Regulatory index, and the results are similar to the results obtained using Regulatory index.
} 
regulation in both tables. This result suggests that banks with a CRO executive (compared to banks without a CRO executive) were more involved in the credit boom and bust if located in a country with lax regulation. One explanation for this may be reverse causality: banks which were involved in the boom made sure they had strong risk management, especially in countries with external oversight. The Appendix 4c results suggest that the relation between bank governance and risk management and Credit growth in the crisis does not vary significantly with the quality of regulatory framework.

The Appendix 4d results suggest that the relation between bank governance and incrisis credit losses does depend on regulation. In particular, the negative coefficient for the interaction term Board foreign * Lax regulation suggests that a higher share of foreign members in the supervisory board is associated with fewer non-performing loans in the crisis, especially in countries with a lax regulatory framework. This finding is confirmed by the significant negative interaction term for Foreign ownership * Lax regulation in the same table.

\subsection{Changes in risk management and corporate governance}

There is increasing evidence in the literature that past experiences of financial institutions affect their subsequent business model and performance (Power et al., 2013). One may expect therefore that losses incurred by banks during the crisis may lead a bank to improve its risk management and governance structures. Alternatively, it could be the case that structural features of a bank's business model, risk management and governance that make the bank more sensitive to crises are too expensive to change or are not profitable (Fahlenbrach et al., 2012).

In order to assess the existence of a learning process from the crisis, we examine in Table 6 the changes in the Risk management index and Supervisory board index across banks from the onset of the crisis to the end of the crisis. Our data shows that between 2007 and 2012 risk management improved significantly: the Risk management index of banks in our sample increased, on average, from 0.40 in 2007 to 0.58 in 2012. By contrast we see only a minor improvement in the Supervisory board index from 0.56 on average in 2007 to 0.58 in 2012.

\section{Table 6 here}

In Table 6 we examine whether banks which were hit hardest by the crisis improved 
their risk management and governance more than banks that were hit less by the crisis. We split our sample into banks with high (i.e. above median) NPLs in the crisis and banks with low (i.e. below median) NPLs in crisis. We then conduct a difference-in-difference analysis comparing average changes in the Risk management index and Supervisory board index from 2007 to 2012 for these two groups of banks.

The results presented in Table 6 show that both banks with high and low credit losses in the crisis improve their risk management significantly. Interestingly though, those banks that experienced more Credit losses during the crisis improve their Risk management index (0.136) less than banks that experienced low Credit losses during the crisis (0.227). Thus in line with the results of Fahlenbrach et al. (2012) those banks that were hit more by the credit boom and bust cycle display less organizational learning. Neither group of banks show a significant increase in the Supervisory board index.

\section{Conclusions}

In this paper we use a unique, hand-collected dataset covering 156 banks in Central and Eastern Europe from 2005 through 2012, to examine how risk management and corporate governance influences bank involvement in a credit boom and bust cycle.

With respect to risk management we show that a strong risk committee is associated with more moderate pre-crisis credit growth but not with fewer credit losses. With respect to bank governance we document that a higher share of financial experts on the supervisory board is associated with more rapid credit growth in the pre-crisis period and a larger contraction of credit in the crisis period, but not with larger credit losses. A higher share of foreign members on the board of a bank is associated with fewer credit losses in the crisis, especially in countries with lax regulation. Finally, we find no evidence of an organizational learning process among crisis-hit banks: Those banks with the largest credit losses during the crisis are least likely to improve their risk management in the aftermath of the crisis.

Our results contribute to a better understanding of how bank governance may affect risk-taking in credit boom and bust cycles, especially in emerging economies. First, we confirm recent findings for the U.S. suggesting that banks were pushed by financial expert members on their boards to increase risk-taking in the pre-crisis credit boom (see Minton et al. 2014). However, our results suggest that while expert members may have led banks to expand and contract credit more aggressively they also seem to have helped contain the 
corresponding exposure to credit risk. Second, our results suggest the share of foreign members on the supervisory board - as opposed to foreign ownership per se - may help contain the credit risk in emerging economies, although foreign board members may not necessarily stop a bank from getting involved in a credit boom in the first place.

Our results raise further questions with respect to the role of internal risk management is mitigating credit risk exposure in emerging economies: It is puzzling why banks with stronger risk committees (but not with stronger risk officers) are less likely to participate in the credit boom, but end up with larger credit losses in the crisis. It is further puzzling why banks which experience large credit losses are less likely to change risk management in the aftermath of the crisis. It seems reasonable to assume that internal risk-management in banks is strongly endogenous to the banks business model. More research is thus necessary to understand the interrelation between inherent risk exposure from banks business models, their endogenous choices of risk management processes and the resulting realization of credit losses. 


\section{References}

Adams, R., Ferreira, D. (2007) A theory of friendly boards. Journal of Finance, 62(1): 217-50.

Adams, R., Mehran, H. (2012) Bank board structure and performance: Evidence for large bank holding companies, Journal of Financial Intermediation, 21(2): 243-267.

Aebi, V., Sabato, G., Schmid, M. (2012) Risk Management, Corporate Governance, and Bank Performance in the Financial Crisis, Journal of Banking and Finance, 36(12): 32133226.

Allen, F., Gu, X., Kowalewski, O. (2013) Corporate governance and intra-group transactions in European bank holding companies during the crisis, Global Banking, Financial Markets and Crises, International Finance Review, 14: 365-431.

Altunbas, Y., Manganelli, S., Marqués-Ibanez, D. (2011) Bank risk during the financial crisis: do business models matter? European Central Bank Working Paper, No. 1394.

Barth, J., Caprio, G., Levine, R. (2004) Bank Regulation and Supervision: What Works Best? Journal of Financial Intermediation, 13: 205-48.

Basel Committee on Banking Supervision (2010) Principles for enhancing corporate governance, October 2010.

Beck, T., Demirguc-Kunt, A., Levine, R. (2006) Bank Supervision and Corruption in Lending, Journal of Monetary Economics, 53: 2131-63.

Beltratti, A., Stulz, R. (2012) The Credit Crisis around the Globe: Why did some Banks Perform better? Journal of Financial Economics, 105(1): 1-17.

Berger, A., Imbierowicz, B., Rauch, C. (2013) The Roles of Corporate Governance in Bank Failures during the Recent Financial Crisis (August 27, 2013). Available at SSRN:http://ssrn.com/abstract=2021799 or http://dx.doi.org/10.2139/ssrn.2021799.

Berger, A., Makaew, T., Turk-Ariss, R. (2014) Foreign Banks and Lending to Small and Large Firms during Normal Times and Financial Crises. Unpublished manuscript.

Brown, M., De Haas, R. (2012), Foreign Currency Lending in Emerging Europe: Bank-level Evidence, Economic Policy, 27(69): 59-98.

Buch, C., DeLong, G. (2008) Do weak supervisory systems encourage bank risktaking? Journal of Financial Stability, 4(1): 23-39.

Choi, M.J., Gutierrez, E., Martinez Peria, M.S. (2013) Dissecting Foreign Bank Lending Behavior During the 2008-2009 Crisis, The World Bank Policy Research Working Paper 6674.

Chortareas G., Girardone C., Ventouri, A. (2013) Financial freedom and bank efficiency: Evidence from the European Union. Journal of Banking and Finance 37: 12231231.

Claessens, S., van Horen, N. (2012) Being a foreigner among domestic banks: Asset or liability? Journal of Banking \& Finance, 36: 1276-1290.

Claessens, S., van Horen, N. (2014) Foreign banks: Trends and impact, Journal of Money, Credit and Banking, 46(1): 295-326. 
Committee of European Banking Supervisors (CEBS) (2010) High level principles for risk management, (February 16, 2010, No. 9), 25, http://www.eba.europa.eu/documents/10180/16094/HighLevelprinciplesonriskmanagement.p $\underline{\mathrm{df}}$

Cornett, M.M., McNutt, J.J., Tehranian, H. (2010) The financial crisis, internal corporate governance, and the performance of publicly-traded U.S. bank holding companies, Unpublished working paper, Boston College.

De Andres, P., Vallelado, E. (2008) Corporate governance in banking: The role of the board of directors, Journal of Banking \& Finance, 32(12): 2570-2580.

De Haan, J., Vlahu, R. (2013) Corporate governance of banks: A survey, DNB Working Papers 386.

De Haas, R., Korniyenko, Y., Pivovarsky, A., Tsankova, T. (2014 forthcoming) Taming the Herd? Foreign Banks, the Vienna Initiative and Crisis Transmission, Journal of Financial Intermediation.

Delis, M.D., Staikouras, P. (2011) Supervisory Effectiveness and Bank Risk, Review of Finance, 15: 511-543.

Dell’Ariccia, G., Igan, D., Laeven, L. (2012) Credit Booms and Lending Standards: Evidence from the Subprime Mortgage Market, Journal of Money, Credit and Banking, 44(23): 367-384.

Demirguc-Kunt, A., Detragiache, E., Tressel, T. (2008) Banking on the Principles: Compliance with Basel Core Principles and Bank Soundness, Journal of Financial Intermediation, 17: 511-42.

Demirguc-Kunt, A., Detragiache, E., Merrouche, O. (2013) Bank Capital: Lessons from the Financial Crisis, Journal of Money, Credit and Banking, 45: 1147-1164.

Demirguc-Kunt, A., Laeven, L., Levine, R. (2004) Regulations, Market Structure, Institutions, and the Cost of Financial Intermediation, Journal of Money, Credit and Banking, 36: 593-622.

Ellul, A., Yerramilli, V. (2013) Stronger Risk Controls, Lower Risk: Evidence from U.S. Bank Holding Companies, The Journal of Finance, 68(5): 1757-1803.

Erkens, D., Hung, M., Matos, P. (2012) Corporate governance in the 2007-2008 financial crisis: Evidence from financial institutions worldwide, Journal of Corporate Finance, 18(2): 389-411.

European Investment Bank (EIB) (2013) Banking in Central and Eastern Europe and Turkey - Challenges and Opportunities, http://vienna-initiative.com/wpcontent/uploads/2013/02/Banking-in-Central-and-Eastern-Europe-and-Turkey-Challengesand-Opportunities.pdf

Fahlenbrach, R., Prilmeier, R., Stulz, R. (2012) This Time is the Same: Using Bank Performance in 1998 to Explain Bank Performance During the Recent Financial Crisis, Journal of Finance, 67: 2139-2185.

Fernandes, N., Fich, E. M. (2013) Does Financial Experience Help Banks during Credit Crises? Available at SSRN: http://ssrn.com/abstract=1409557 orhttp://dx.doi.org/10.2139/ssrn.1409557 
Feyen, E., Letelier, R., Love, I., Maimbo, S.M., Rocha, R. (2014) The Impact of Funding Models and Foreign Bank Ownership on Bank Credit Growth Is Central and Eastern Europe Different? The World Bank Policy, Research Working Paper 6783.

Foos, D., Norden, L., Weber, M. (2010) Loan growth and riskiness of banks, Journal of Banking \& Finance, 34: 2929-2940.

Gropp, R., Heider, F. (2010) The Determinants of Bank Capital Structure, Review of Finance, 14(4): 587-622.

Güner, B., Malmendier, U., Tate, G. (2008) Financial expertise of directors, Journal of Financial Economics, 88(2): 323-354.

Illueca, M., Norden, L., Udell, G. (2014) Liberalization and Risk-Taking: Evidence from Government-Controlled Banks, Review of Finance, 18: 1217-1257.

John, K., Litov, L., Yeung, B. (2008). Corporate governance and managerial risk taking: theory and evidence, Journal of Finance, 63: 1679-1728.

Keys, B., Mukherjee, T., Seru, A., Vig, V. (2009) Financial regulation and securitization: Evidence from subprime loans, Journal of Monetary Economics, 56(5): 700720.

Kirkpatrick, G. (2009) The Corporate Governance Lessons from the Financial Crisis, OECD Financial Market Trends, 1: 1-30.

Laeven, L., Levine, R. (2009) Bank Governance, Regulation and Risk Taking, Journal of Financial Economics 93: 259-275.

Landier, A., Sraer, D., Thesmar, D. (2009) Financial Risk Management: When Does Independence Fail? American Economic Review: Papers \& Proceedings, 99(2): 454-458.

Maechler, A., Mitra, S., Worrell, D. (2010) Decomposing Financial Risks and Vulnerabilities in Emerging Europe, IMF Staff Papers, 57: 25-60.

Minton, B., Taillard, J., Williamson. R. (2014 Forthcoming). Financial Expertise of the Board, Risk Taking, and Performance: Evidence from Bank Holding Companies, Journal of Financial and Quantitative Analysis, http://dx.doi.org/10.1017/S0022109014000283.

Ongena, S., Popov, A., Udell, G. (2013) "When the cat's away the mice will play": Does regulation at home affect bank risk-taking abroad? Journal of Financial Economics, 18: 727-750.

Pathan, S. (2009) Strong boards, CEO power and bank risk-taking, Journal of Banking and Finance, 33: 1340-1350.

Power, M., Ashby, S., Palermo, T. (2013) Risk Culture in Financial Organisations. A Research Report, CARR Report http://www.lse.ac.uk/researchAndExpertise/units/CARR/pdf/Final-Risk-Culture-Report.pdf

Shleifer, A., Vishny, R. W. (1997) A Survey of Corporate Governance, The Journal of Finance, 52: 737-783.

Stulz, R. (2014) Governance, Risk Management, and Risk-Taking in Banks, NBER Working Paper 20274.

Walker, D. (2009) A review of corporate governance in UK banks and other financial industry entities - Final recommendations, November 26, 2009, 9, http://webarchive.nationalarchives.gov.uk/+/http:/www.hm-

treasury.gov.uk/d/walker_review_261109.pdf 
Figure 1a Annual growth of private credit by region

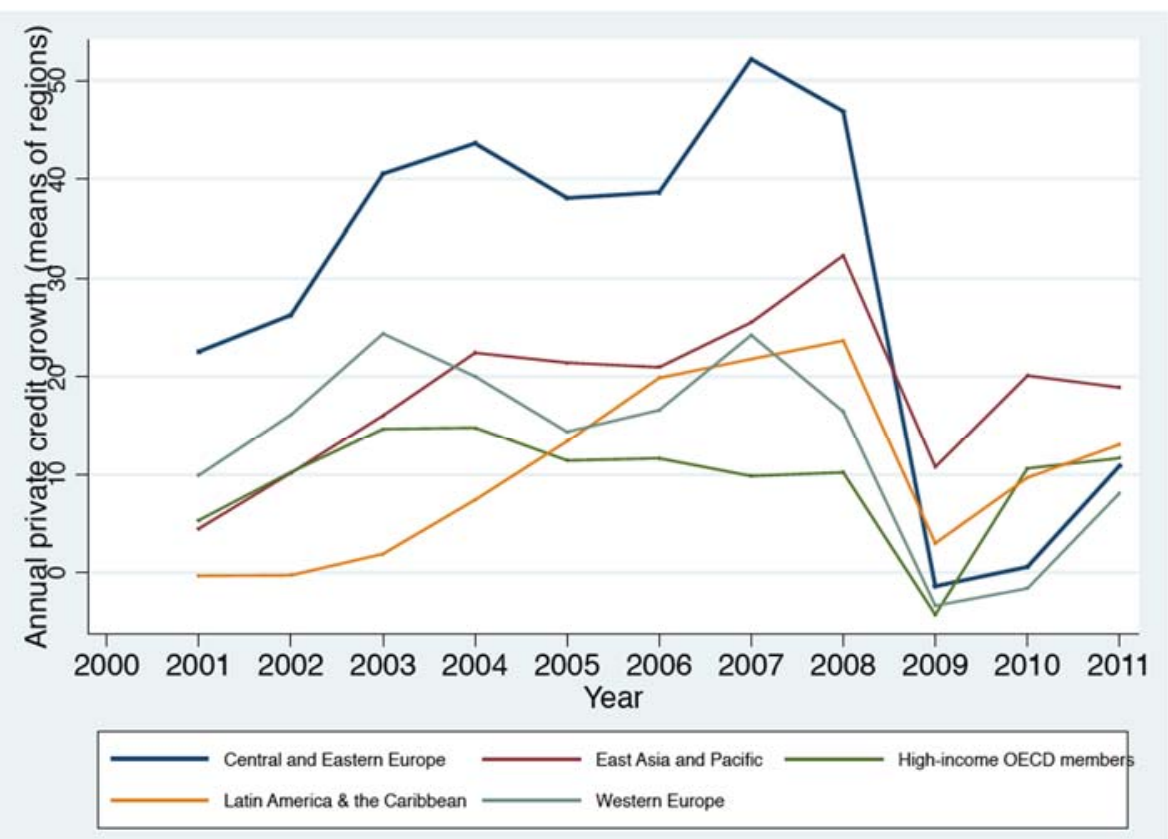

This figure displays average annual growth of Bank credit to the private sector by region. Annual private credit growth measured using annual changes of Bank private credit - the financial resources provided to the private sector by commercial banks and other financial institutions that accept transferable deposits. (Source Global Financial Development Database (GFDD)).

Figure 1b Non performing loans by region

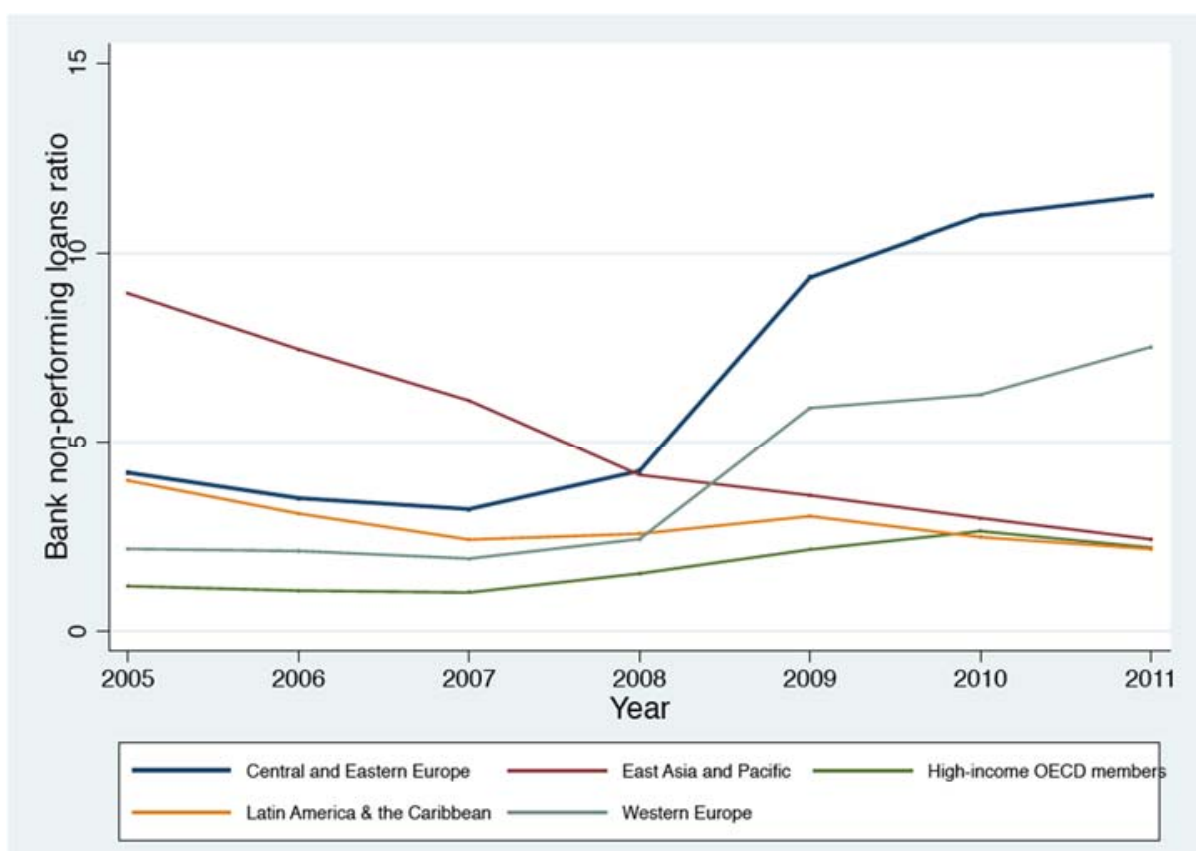

This figure shows the development of NPLs ratio in Central and Eastern Europe comparing to other emerging market regions. NPLs ratio measured using Bank non-performing loans to gross loans (\%) - Ratio of defaulting loans (payments of interest and principal past due by 90 days or more) to total gross loans (total value of loan portfolio) (Source Global Financial Development Database (GFDD)). 
Figure 1c Pre-crisis credit growth and Non-performing loans during crisis

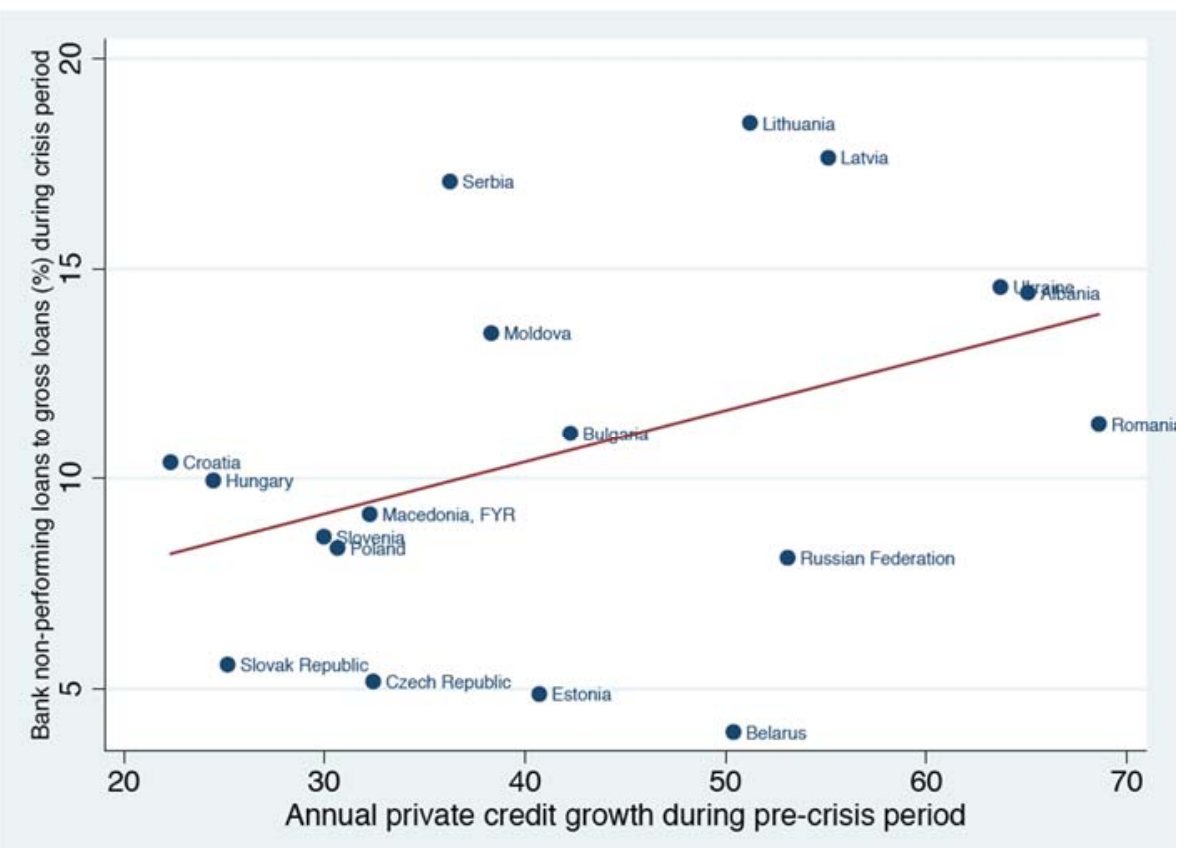

This figure plots the NPLs ratio during crisis period against Annual private credit growth during pre-crisis period. Pre-crisis denotes the period 2005-2007 and Crisis denotes the period 2008-2011. Annual private credit growth measured using annual changes of Bank private credit - the financial resources provided to the private sector by commercial banks and other financial institutions that accept transferable deposits. NPLs ratio measured using Bank non-performing loans to gross loans (\%) - Ratio of defaulting loans (payments of interest and principal past due by 90 days or more) to total gross loans (total value of loan portfolio) (Source Global Financial Development Database (GFDD)). 
Figure 2 Home and host countries of banks in our sample

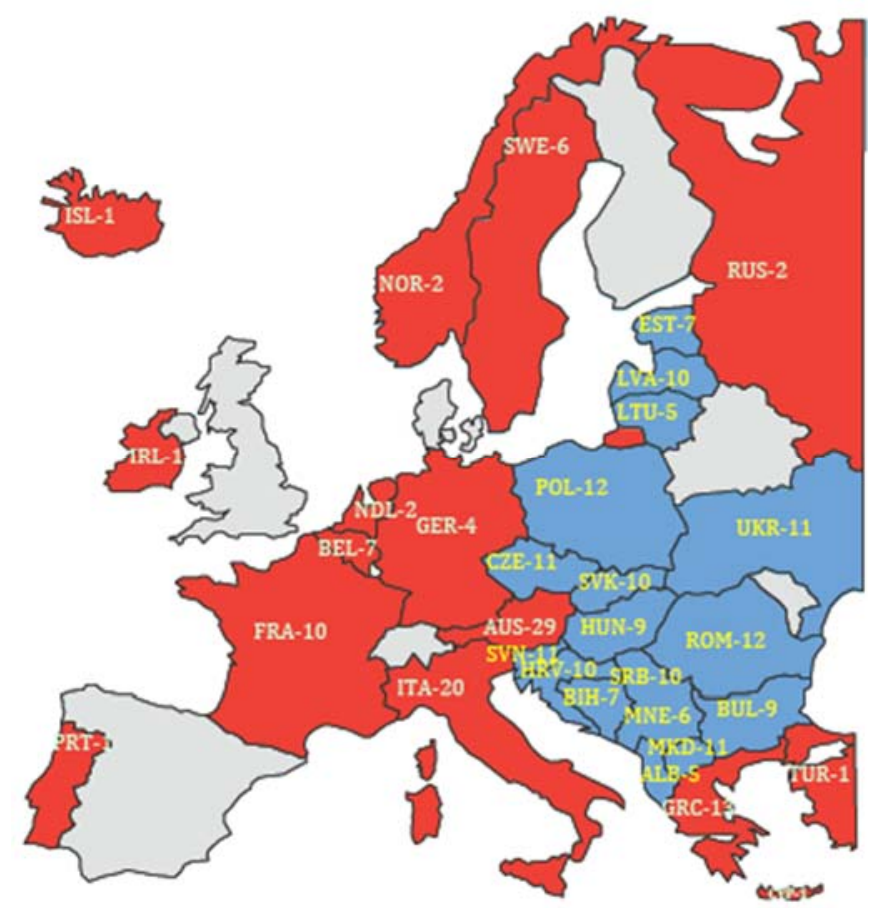

This figure displays the cross-border dimension of the underlying data. Countries in blue color (Albania, Bosnia and Herzegovina, Bulgaria, Croatia, Czech Republic, Estonia, Hungary, Latvia, Lithuania, Macedonia, Montenegro, Poland, Romania, Serbia, Slovakia, Slovenia, and Ukraine) are those where the banks in the dataset are incorporated (host countries).Countries in red color (Austria, Belgium, Cyprus, France, Germany, Greece, Iceland, Ireland, Italy, Netherlands, Norway, Portugal, Russia, Sweden, Turkey, and United States) are those in which the parents of the foreign-owned banks in the dataset are incorporated (home countries). 
Figure 3a Risk management index by country

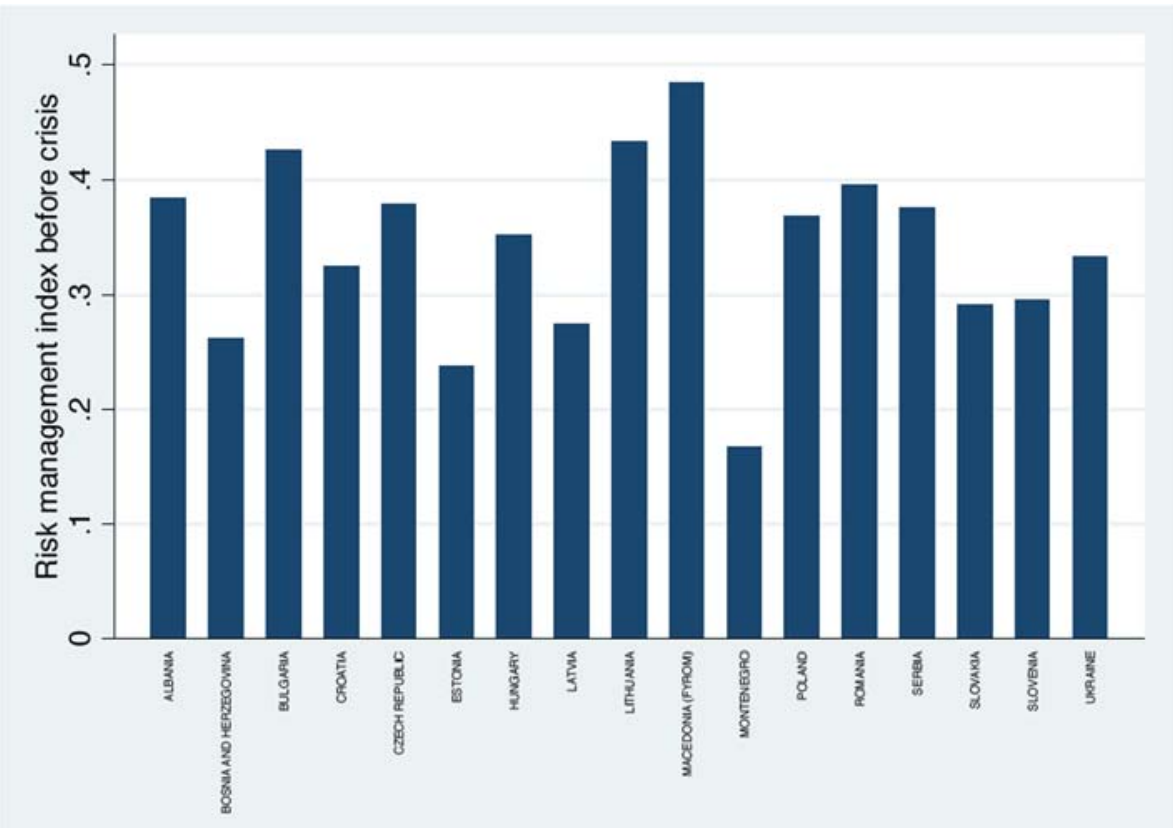

The figure displays mean Risk management index by country during pre-crisis period. Pre-crisis denotes the period 2005-2007.

Figure 3b Risk management index by international banking group

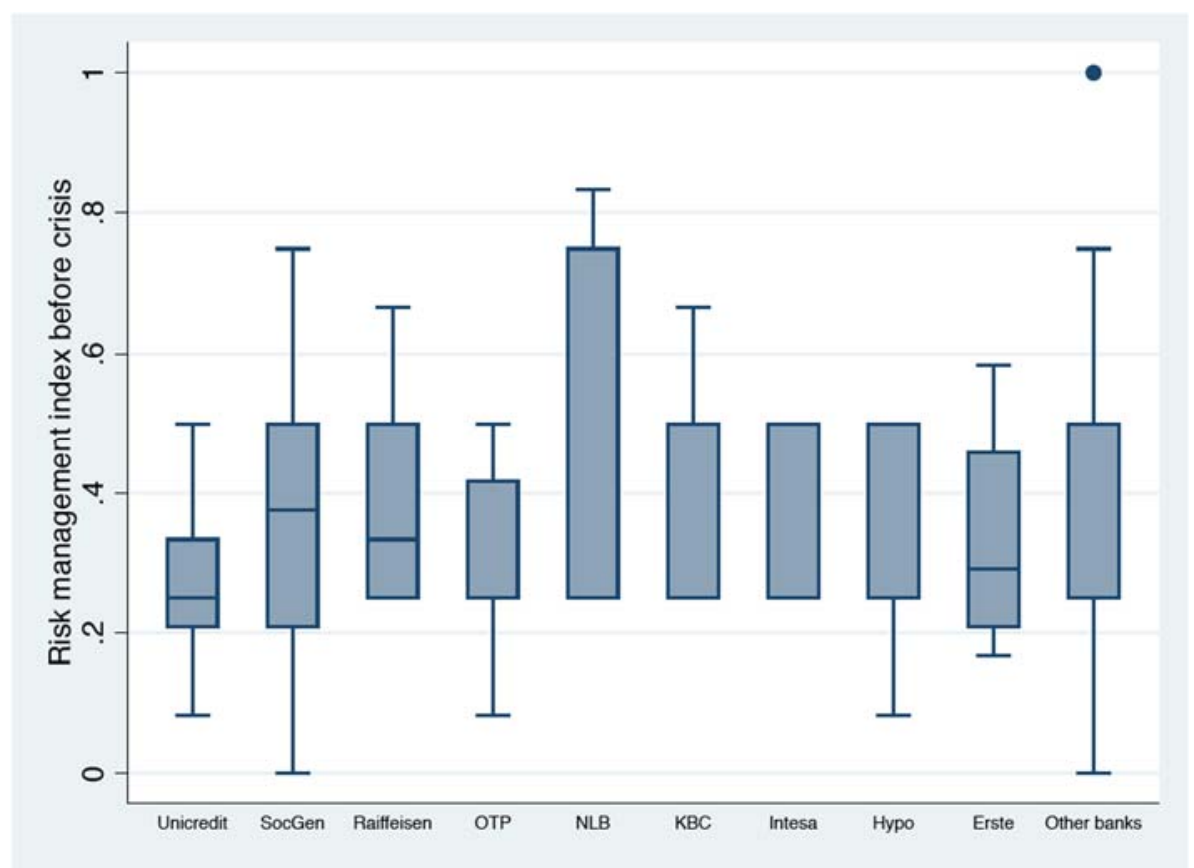

This figure displays the variation of Risk management index across international banking groups during pre-crisis period. We present only banking groups for which we have information on at least 5 subsidiaries in the region. Pre-crisis denotes the period 2005-2007. 
Figure 3c Supervisory board index by country

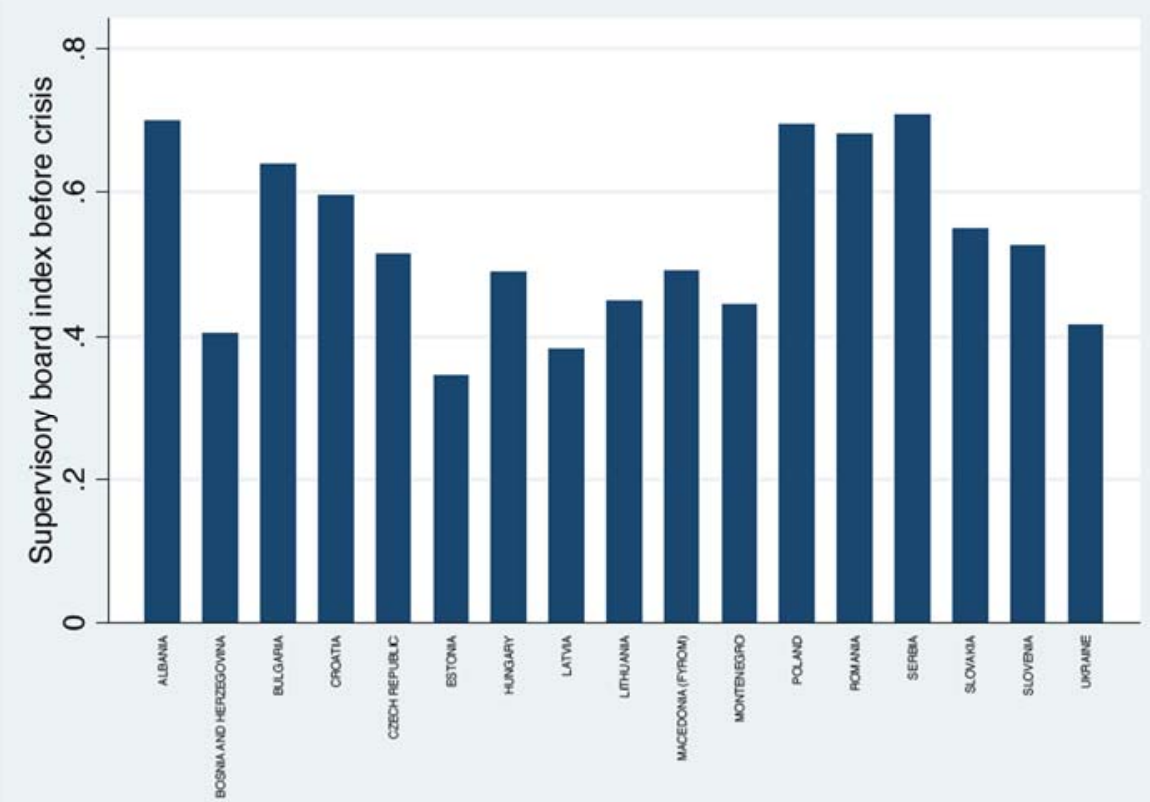

The figure displays mean Supervisory board index by country during pre-crisis period. Pre-crisis denotes the period 2005-2007.

Figure 3d Supervisory board index by international banking group

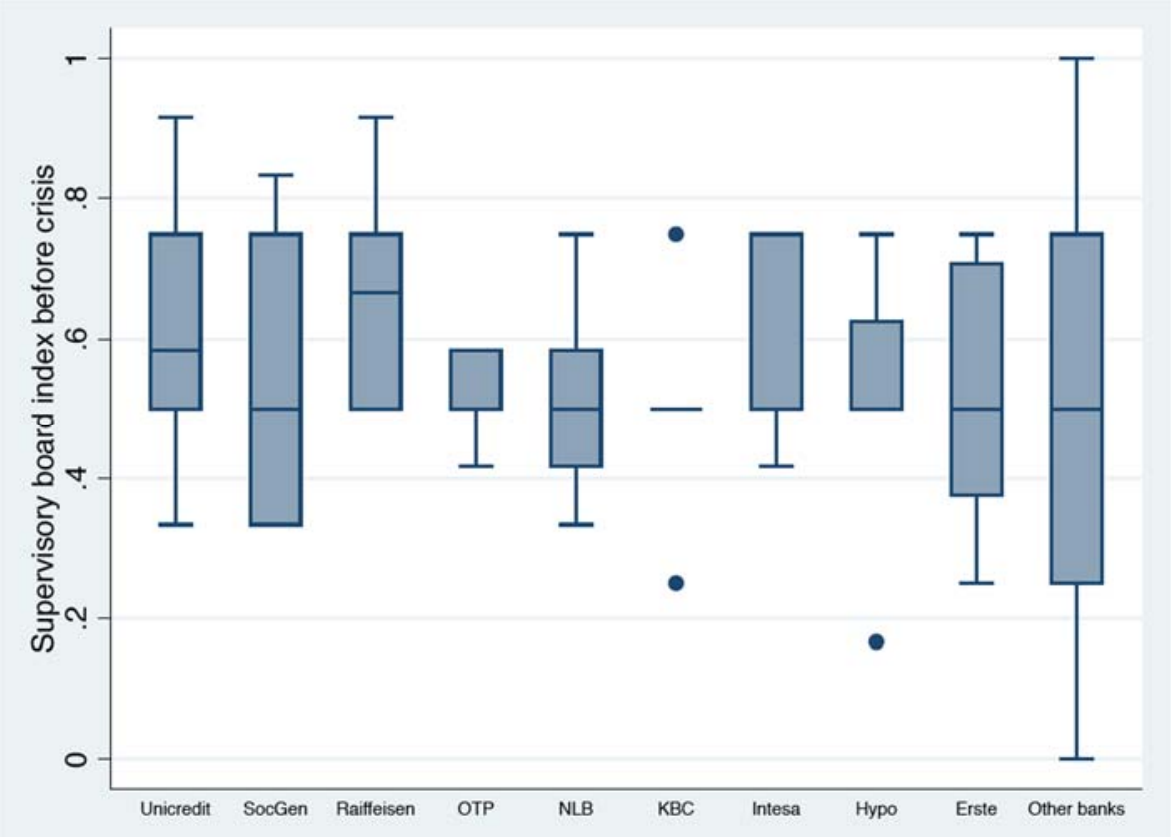

This figure displays the variation of Supervisory board index across international banking groups during pre-crisis period. Pre-crisis denotes the period 20052007. We present only banking groups for which we have information on at least 5 subsidiaries in the region 
Figure 3e Risk management index and Supervisory board index by bank

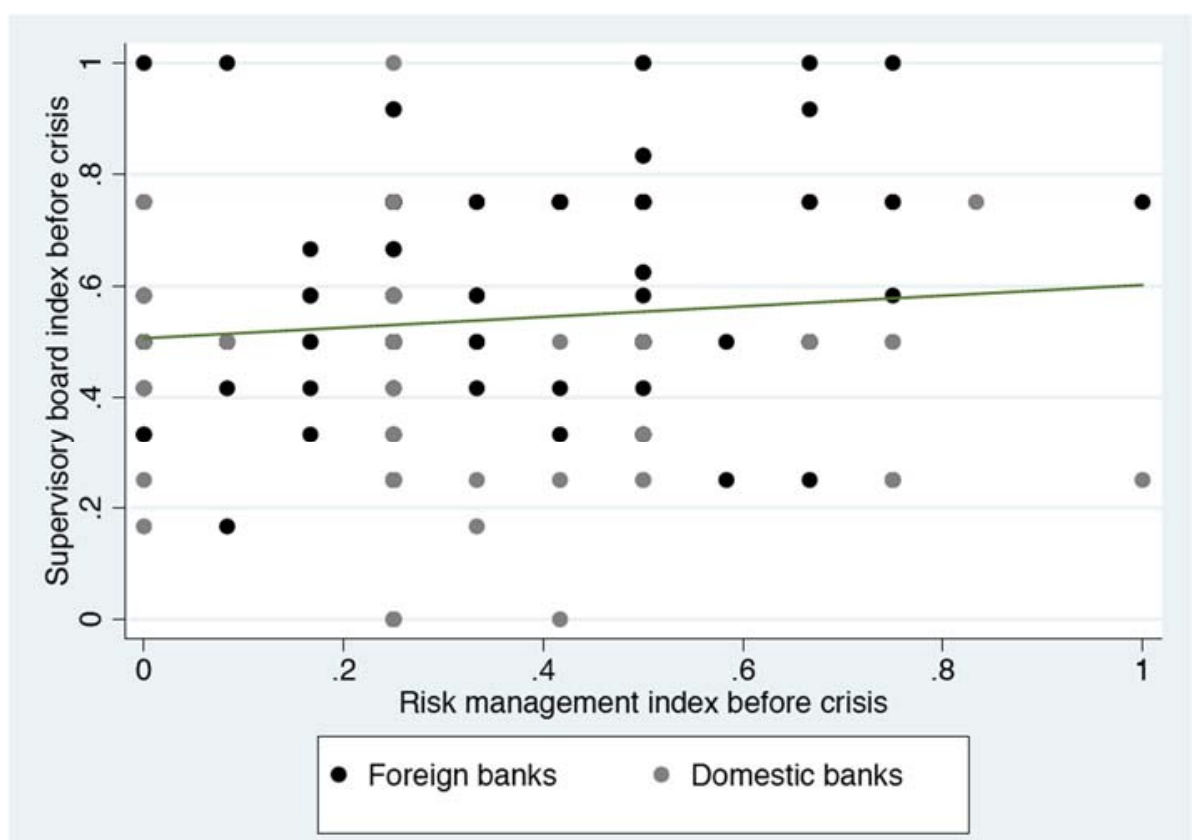

This figure plots the Supervisory board index (mean 2005-2007) against the Risk management index (mean 2005-2007). Domestic banks are coloured gray, foreign banks are coloured black. We classify banks into foreign and domestic banks depending on whether $50 \%$ or more of banks' shares are owned by foreigners or by central, local governments or domestic private actors. 
Figure 4a Pre-crisis credit growth and credit growth during the crisis

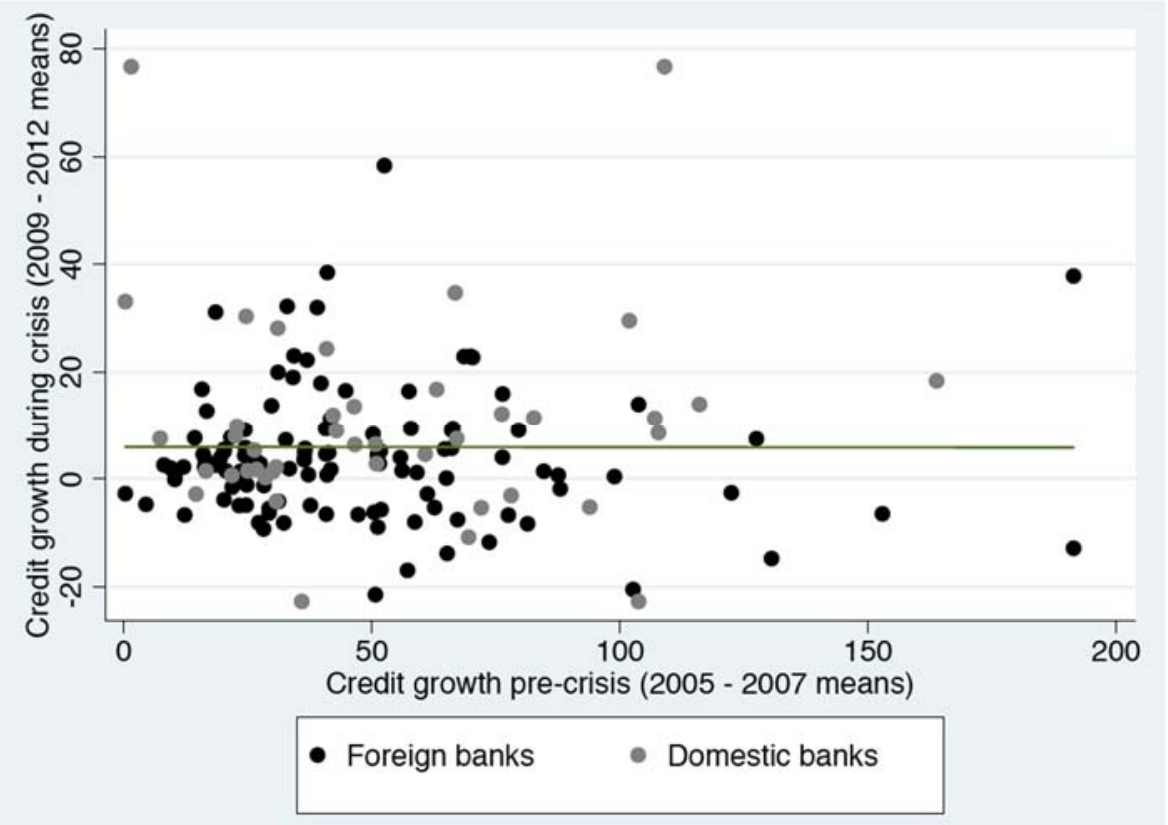

This figure plots the Credit growth during pre-crisis period against Credit growth during crisis at the bank level. Credit growth is measured as Annual Growth of Gross Loans (\%). Domestic banks are coloured gray, foreign banks are coloured black. We classify banks into foreign and domestic banks depending on whether $50 \%$ or more of banks' shares are owned by foreigners or by central, local governments or domestic private actors. Pre-crisis denotes the period 20052007 and Crisis denotes the period 2009-2012

Figure 4b Pre-crisis credit growth and credit drop during the crisis

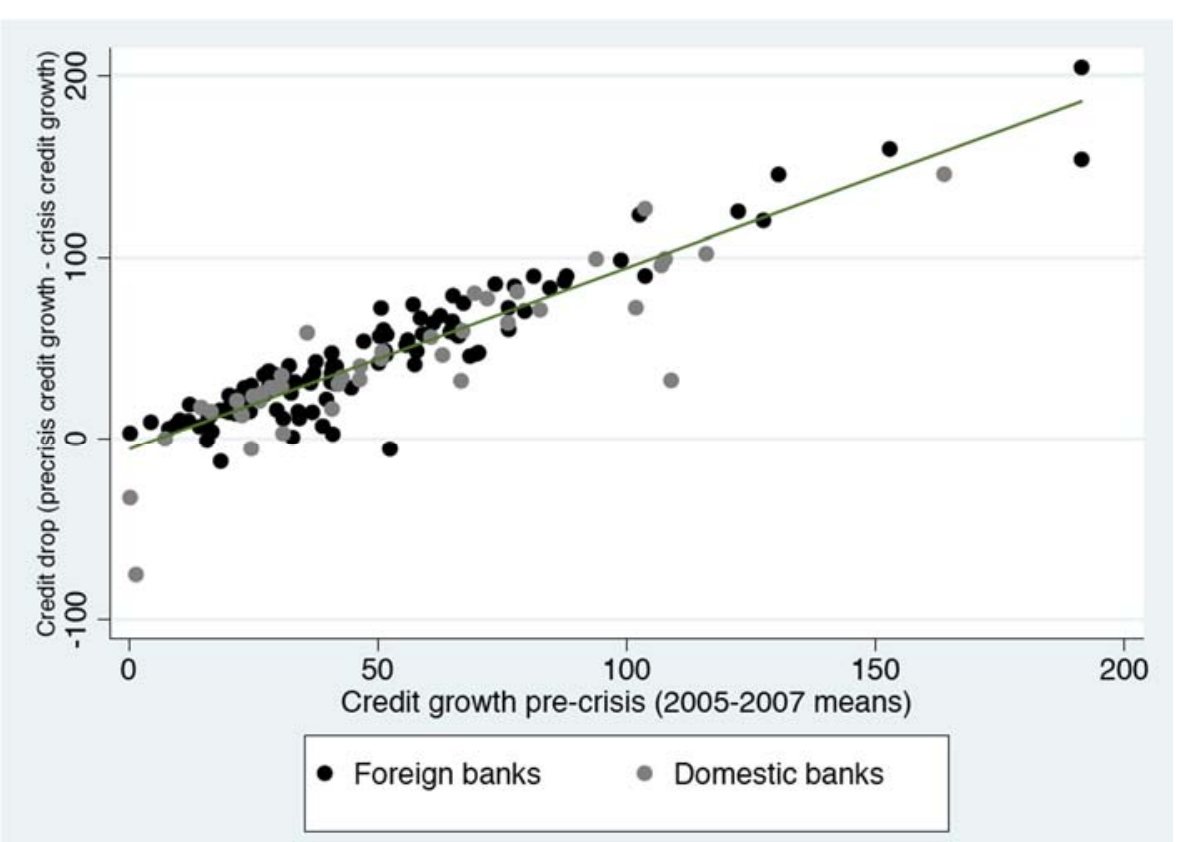

This figure plots the Credit growth during pre-crisis period against Credit drop during crisis at the bank level. Credit growth is measured as Annual Growth of Gross Loans (\%) and Credit drop is measured as (Average pre-crisis Credit growth - Average crisis Credit growth). Domestic banks are coloured gray, foreign banks are coloured black. We classify banks into foreign and domestic banks depending on whether $50 \%$ or more of banks' shares are owned by foreigners or by central, local governments or domestic private actors. Pre-crisis denotes the period 2005-2007 and Crisis denotes the period 2009-2012 
Figure 4c Pre-crisis credit growth and non-performing loans during the crisis

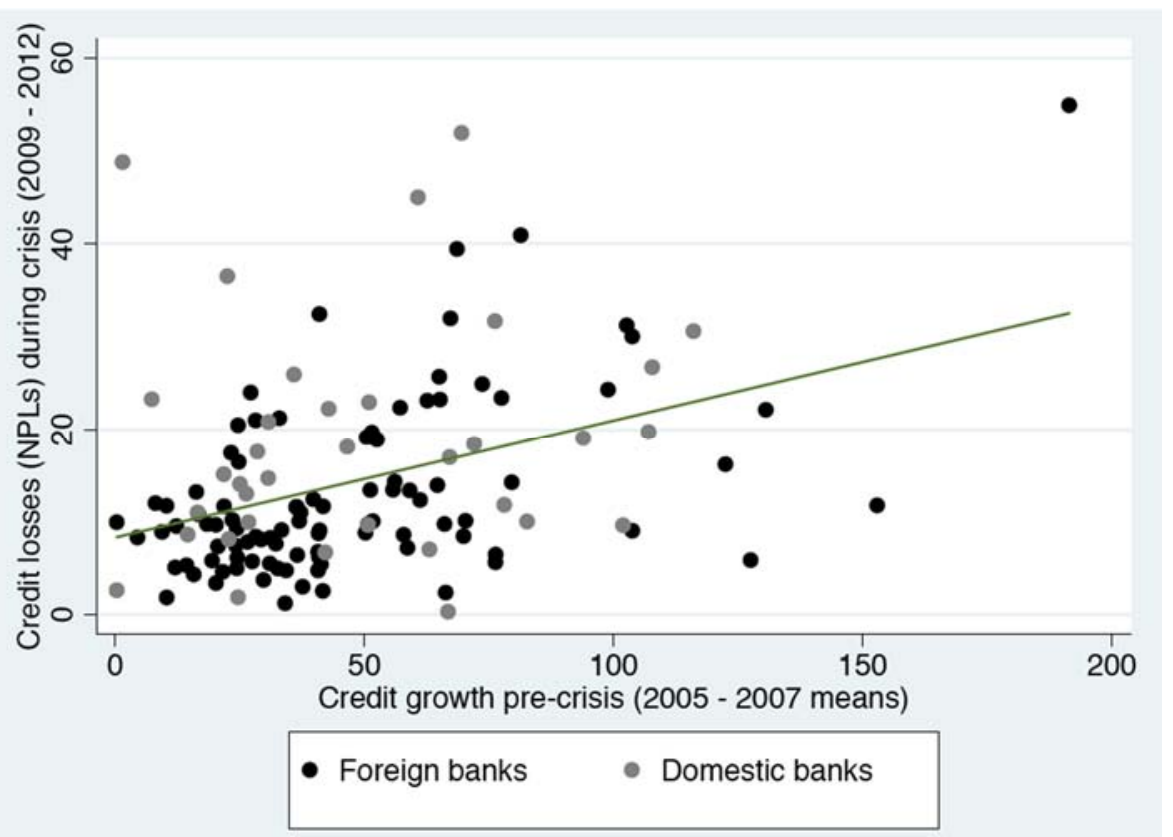

This figure plots the Credit growth during pre-crisis period against NPLs during crisis at the bank level. Credit growth is measured as Annual Growth of Gross Loans (\%) and NPLs is measured as Impaired Loans(NPLs)/ Gross Loans (\%). Domestic banks are coloured gray, foreign banks are coloured black. We classify banks into foreign and domestic banks depending on whether $50 \%$ or more of banks' shares are owned by foreigners or by central, local governments or domestic private actors. Pre-crisis denotes the period 2005-2007 and Crisis denotes the period 2009-2012. The pairwise correlation between the two indicators is 0.3909 . 
Figure 5 Regulatory and supervisory framework by host country

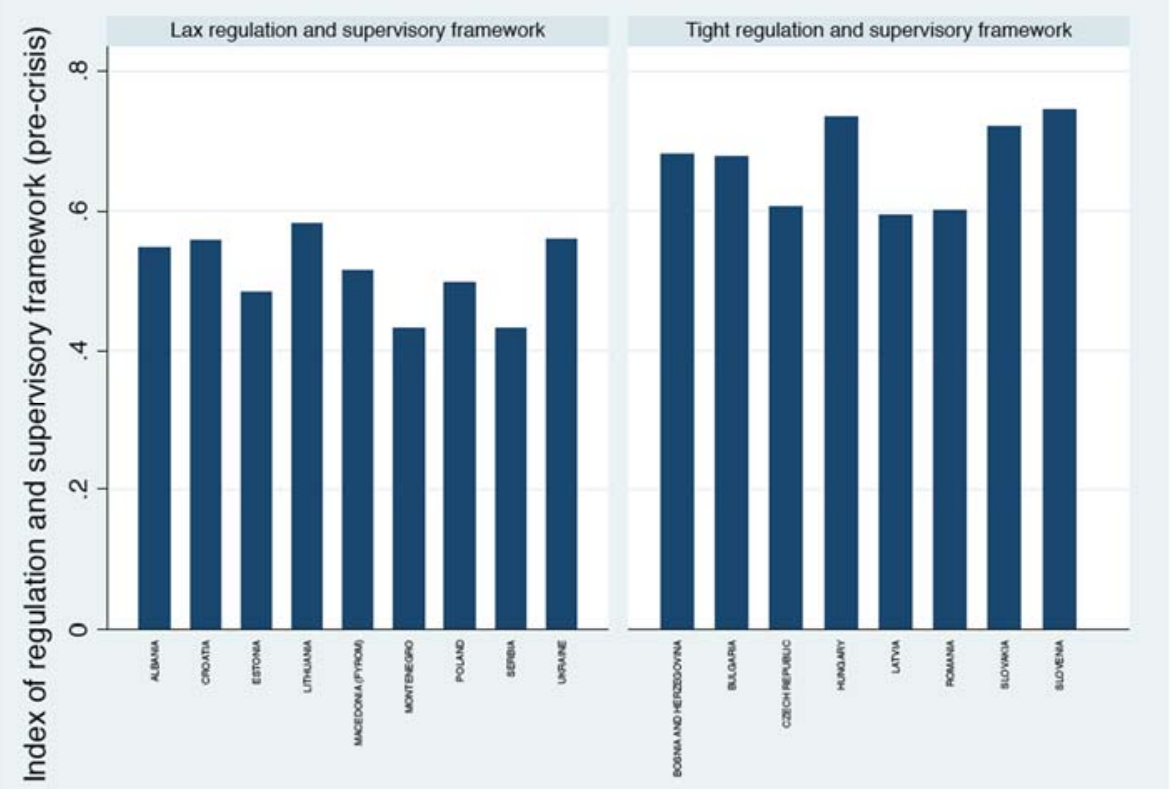

The figure displays mean Index of regulation and supervisory framework by country during pre-crisis period. Pre-crisis denotes the period 2005-2007. We define a host country as a country with a lax regulation if the value of Index of regulation and supervisory framework for that country is lower than the median value of Index of regulation and supervisory framework for the entire sample of countries, otherwise as a country with a tight regulation. 
Table 1 Panel A Descriptive statistics of bank level variables

\begin{tabular}{|c|c|c|c|c|c|c|c|c|}
\hline & Obs & Mean & $\begin{array}{l}\text { Std. } \\
\text { Dev. }\end{array}$ & Min & Max & $\begin{array}{c}\text { Foreign } \\
\text { banks } \\
\text { (mean) }\end{array}$ & $\begin{array}{c}\text { Domestic } \\
\text { banks } \\
\text { (mean) }\end{array}$ & Difference \\
\hline Credit growth (pre-crisis) & 156 & 49.48 & 35.25 & -19.96 & 195.48 & 48.08 & 53.29 & $-5.205^{* *}$ \\
\hline Credit drop (crisis) & 156 & 43.68 & 37.99 & -75.22 & 204.28 & 44.20 & 42.35 & -1.853 \\
\hline Credit growth (crisis) & 156 & 5.82 & 14.82 & -22.73 & 76.66 & 3.96 & 10.93 & $-6.973 * * *$ \\
\hline Credit losses - NPLs (crisis) & 156 & 14.35 & 10.42 & 0.32 & 54.93 & 12.85 & 18.32 & $-5.468 * * *$ \\
\hline CRO present (pre-crisis) & 156 & 0.84 & 0.34 & 0.00 & 1.00 & 0.85 & 0.79 & $0.0604 * *$ \\
\hline CRO executive (pre-crisis) & 156 & 0.21 & 0.38 & 0.00 & 1.00 & 0.24 & 0.13 & $0.107 * * *$ \\
\hline Risk committee (pre-crisis) & 156 & 0.20 & 0.34 & 0.00 & 1.00 & 0.18 & 0.23 & $-0.0428 *$ \\
\hline $\begin{array}{l}\text { Risk committee reports to } \\
\text { board (pre-crisis) }\end{array}$ & 156 & 0.14 & 0.31 & 0.00 & 1.00 & 0.12 & 0.18 & $-0.0660 * * *$ \\
\hline Board size (pre-crisis) & 156 & 6.54 & 2.20 & 3.00 & 15.00 & 6.72 & 6.17 & $0.0781^{* * *}$ \\
\hline Board expertise (pre-crisis) & 156 & 0.88 & 0.18 & 0.15 & 1.00 & 0.92 & 0.78 & $0.143^{* * *}$ \\
\hline $\begin{array}{l}\text { Board independence (pre- } \\
\text { crisis) }\end{array}$ & 156 & 0.17 & 0.21 & 0.00 & 1.00 & 0.15 & 0.25 & $-0.103^{* * *}$ \\
\hline Board foreign (pre-crisis) & 156 & 0.56 & 0.34 & 0.00 & 1.00 & 0.70 & 0.17 & $0.531^{* * *}$ \\
\hline $\begin{array}{l}\text { Risk management index } \\
\text { (pre-crisis) } \\
\text { Supervisory board index } \\
\text { (pre-crisis) }\end{array}$ & $\begin{array}{r}156 \\
156 \\
-\end{array}$ & 0.35 & 0.22 & 0.00 & 1.00 & 0.35 & 0.33 & 0.0145 \\
\hline $\begin{array}{l}\text { Size of bank (mil. EUR) } \\
\text { (pre-crisis) } \\
\text { Capital structure - }\end{array}$ & 156 & 4825.85 & 7071.20 & 40.80 & 38100.00 & 4860.97 & 3590.41 & $1270.55^{* * *}$ \\
\hline $\begin{array}{l}\text { Equity/TA (pre-crisis) } \\
\text { Asset structure - Loan/TA } \\
\text { (pre-crisis) }\end{array}$ & 156 & 11.54 & 6.03 & 3.43 & 35.72 & 10.71 & 13.77 & $3.060 * * *$ \\
\hline
\end{tabular}

Table 1 Panel B Descriptive statistics of regulation and supervision variables

\begin{tabular}{l|ccccc}
\hline \hline & Countries & Mean & $\begin{array}{c}\text { Std. } \\
\text { Dev. }\end{array}$ & Min & Max \\
\hline $\begin{array}{l}\text { Restrictions on Banking } \\
\text { Activities (Host) (pre- } \\
\text { crisis) }\end{array}$ & 17 & 6.82 & 1.36 & 4.00 & 9.00 \\
$\begin{array}{l}\text { Capital Regulatory Index } \\
\text { (Host) (pre-crisis) }\end{array}$ & 17 & 5.76 & 1.29 & 3.67 & 8.00 \\
$\begin{array}{l}\text { Official Supervisory Power } \\
\text { (Host) (pre-crisis) }\end{array}$ & 17 & 10.77 & 2.90 & 3.67 & 14.17 \\
$\begin{array}{l}\text { Regulatory index (Host) } \\
\text { (pre-crisis) }\end{array}$ & 17 & 0.59 & 0.10 & 0.43 & 0.75 \\
\hline \hline
\end{tabular}


Table 2 Risk management and corporate governance and credit growth during the pre-crisis period

This table reports the results of regressions that examine the relation between corporate governance and credit growth during the pre-crisis period. We estimate alternative versions of the following regression specification: Credgr $_{i, c, 2005-2007}=\alpha_{c}+\beta \times$ Gov $_{i, 2005-2007}+\gamma \times$ Control $_{i, 2005-2007}+\varepsilon_{i, c}$

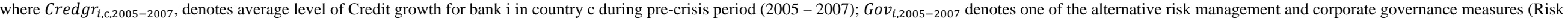

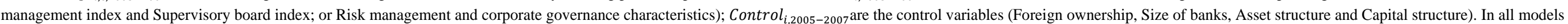

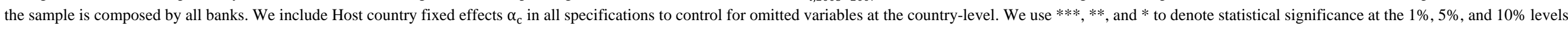
respectively.

\begin{tabular}{|c|c|c|c|c|c|c|c|c|c|c|c|}
\hline $\begin{array}{l}\text { Dependent: Credit } \\
\text { growth (pre-crisis) }\end{array}$ & Model 1 & Model 2 & Model 3 & Model 4 & Model 5 & Model 6 & Model 7 & Model 8 & Model 9 & Model 10 & Model 11 \\
\hline $\begin{array}{l}\text { CRO present (pre- } \\
\text { crisis) } \\
\text { CRO executive (pre- } \\
\text { crisis) } \\
\text { Risk committee (pre- } \\
\text { crisis) } \\
\text { Risk committee reports } \\
\text { to board (pre-crisis) }\end{array}$ & $\begin{array}{l}0.513 \\
(5.51)\end{array}$ & $\begin{array}{l}7.865 \\
(6.52)\end{array}$ & $\begin{array}{r}-9.209 * \\
(4.99)\end{array}$ & $\begin{array}{r}-7.963 * \\
(4.21)\end{array}$ & & & & & & & \\
\hline $\begin{array}{l}\text { Board size (pre-crisis) } \\
\text { Board expertise (pre- } \\
\text { crisis) } \\
\text { Board independence } \\
\text { (pre-crisis) } \\
\text { Board foreign (pre- } \\
\text { crisis) }\end{array}$ & & & & & $\begin{array}{r}1.449 \\
(8.40)\end{array}$ & $\begin{array}{r}34.049 * * \\
(14.47)\end{array}$ & $\begin{array}{r}-9.626 \\
(12.84)\end{array}$ & $\begin{array}{r}-4.141 \\
(16.37)\end{array}$ & & & \\
\hline $\begin{array}{l}\text { Risk management } \\
\text { index (pre-crisis) } \\
\text { Supervisory board } \\
\text { index (pre-crisis) }\end{array}$ & & & & & & & & & $\begin{array}{l}-1.518 \\
(8.56)\end{array}$ & $\begin{array}{r}-4.693 \\
(11.22) \\
\end{array}$ & \\
\hline Foreign ownership & $\begin{array}{r}0.111 \\
(6.41)\end{array}$ & $\begin{array}{r}-0.080 \\
(6.25)\end{array}$ & $\begin{array}{l}-0.510 \\
(6.23)\end{array}$ & $\begin{array}{l}-0.557 \\
(6.21)\end{array}$ & $\begin{array}{l}0.145 \\
(6.39)\end{array}$ & $\begin{array}{r}-4.231 \\
(6.14)\end{array}$ & $\begin{array}{r}-1.271 \\
(6.99) \\
\end{array}$ & $\begin{array}{r}2.435 \\
(13.60) \\
\end{array}$ & $\begin{array}{r}0.053 \\
(6.36) \\
\end{array}$ & $\begin{array}{r}0.845 \\
(7.10) \\
\end{array}$ & $\begin{array}{r}0.105 \\
(6.35) \\
\end{array}$ \\
\hline $\begin{array}{l}\text { Size of bank (pre-crisis) } \\
\text { Capital structure - } \\
\text { Equity/TA (pre-crisis) } \\
\text { Asset structure - } \\
\text { Loan/TA (pre-crisis) }\end{array}$ & $\begin{array}{r}-5.579 \\
(3.20) \\
0.064 \\
(0.57) \\
14.338 \\
(20.67)\end{array}$ & $\begin{array}{r}-6.430^{*} \\
(3.44) \\
-0.011 \\
(0.59) \\
15.356 \\
(20.62)\end{array}$ & $\begin{array}{r}-5.106 \\
(3.08) \\
0.081 \\
(0.52) \\
14.814 \\
(19.72)\end{array}$ & $\begin{array}{r}-5.271 \\
(3.17) \\
0.093 \\
(0.53) \\
16.401 \\
(19.78)\end{array}$ & $\begin{array}{r}-5.666^{*} \\
(3.19) \\
0.054 \\
(0.55) \\
14.481 \\
(20.87)\end{array}$ & $\begin{array}{r}-6.235^{*} \\
(3.11) \\
0.184 \\
(0.53) \\
11.095 \\
(16.03)\end{array}$ & $\begin{array}{r}-5.538 \\
(3.20) \\
0.040 \\
(0.55) \\
12.314 \\
(20.61)\end{array}$ & $\begin{array}{r}-5.411^{*} \\
(2.99) \\
0.054 \\
(0.55) \\
15.242 \\
(18.84)\end{array}$ & $\begin{array}{r}-5.496 \\
(3.24) \\
0.058 \\
(0.54) \\
14.426 \\
(20.46)\end{array}$ & $\begin{array}{r}-5.486 \\
(3.18) \\
0.035 \\
(0.54) \\
14.831 \\
(20.17)\end{array}$ & $\begin{array}{r}-5.574 * \\
(3.19) \\
0.057 \\
(0.55) \\
14.349 \\
(20.52)\end{array}$ \\
\hline Constant & $\begin{array}{r}118.189^{* *} \\
(51.00) \\
\end{array}$ & $\begin{array}{r}129.293^{* *} \\
(53.65) \\
\end{array}$ & $\begin{array}{r}113.781^{* * *} \\
(48.89) \\
\end{array}$ & $\begin{array}{r}114.325^{* *} \\
(49.97) \\
\end{array}$ & $\begin{array}{r}117.172^{* *} \\
(52.74) \\
\end{array}$ & $\begin{array}{r}101.480^{* *} \\
(44.59) \\
\end{array}$ & $\begin{array}{r}122.187^{* *} \\
(51.82) \\
\end{array}$ & $\begin{array}{r}116.443^{* *} \\
(47.76) \\
\end{array}$ & $\begin{array}{r}118.028^{* * *} \\
(51.16) \\
\end{array}$ & $\begin{array}{r}119.335^{* *} \\
(51.31) \\
\end{array}$ & $\begin{array}{r}118.625^{* *} \\
(50.88) \\
\end{array}$ \\
\hline Host country FE & YES & YES & YES & YES & YES & YES & YES & YES & YES & YES & YES \\
\hline $\begin{array}{l}\text { R-squared } \\
\text { N. of cases }\end{array}$ & $\begin{array}{r}0.143 \\
156 \\
\end{array}$ & $\begin{array}{r}0.143 \\
156\end{array}$ & $\begin{array}{r}0.132 \\
156\end{array}$ & $\begin{array}{r}0.138 \\
156 \\
\end{array}$ & $\begin{array}{r}0.143 \\
156 \\
\end{array}$ & $\begin{array}{r}0.195 \\
156 \\
\end{array}$ & $\begin{array}{r}0.156 \\
156 \\
\end{array}$ & $\begin{array}{r}0.136 \\
156 \\
\end{array}$ & $\begin{array}{r}0.144 \\
156 \\
\end{array}$ & $\begin{array}{r}0.141 \\
156 \\
\end{array}$ & $\begin{array}{r}0.144 \\
156\end{array}$ \\
\hline $\begin{array}{l}\text { Mean of dependent } \\
\text { variable }\end{array}$ & 49.47 & 49.47 & 49.47 & 49.47 & 49.47 & 49.47 & 49.47 & 49.47 & 49.47 & 49.47 & 49.47 \\
\hline
\end{tabular}


Table 3 Risk management and corporate governance and credit drop during the crisis period

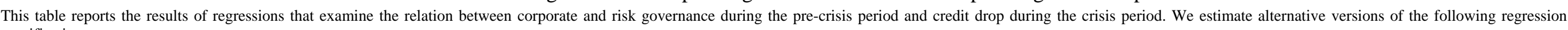
specification:

$\Delta$ Credgr $_{i, c}=\alpha_{c}+\beta \times$ Gov $_{i, 2005-2007}+\gamma \times$ Control $_{i, 2005-2007}+\varepsilon_{i, c}$

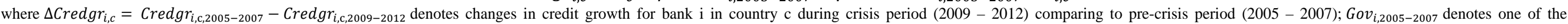

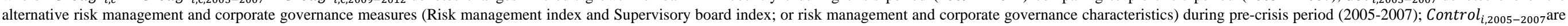

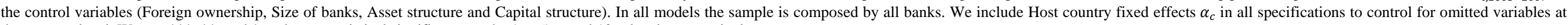
the country-level. We use $* * *, * *$, and * to denote statistical significance at the $1 \%, 5 \%$, and $10 \%$ levels, respectively.

\begin{tabular}{|c|c|c|c|c|c|c|c|c|c|c|c|}
\hline $\begin{array}{l}\begin{array}{l}\text { Dependent: Credit drop } \\
\text { (crisis) }\end{array}\end{array}$ & Model 1 & Model 2 & Model 3 & Model 4 & Model 5 & Model 6 & Model 7 & Model 8 & Model 9 & Model 10 & Model 11 \\
\hline $\begin{array}{l}\text { CRO present (pre- } \\
\text { crisis) } \\
\text { CRO executive (pre- } \\
\text { crisis) } \\
\text { Risk committee (pre- } \\
\text { crisis) } \\
\text { Risk committee reports } \\
\text { to board (pre-crisis) }\end{array}$ & $\begin{array}{r}-4.695 \\
(5.83)\end{array}$ & $\begin{array}{r}4.698 \\
(7.00)\end{array}$ & $\begin{array}{r}-8.776 \\
(5.81)\end{array}$ & $\begin{array}{l}-5.228 \\
(5.25)\end{array}$ & & & & & & & \\
\hline $\begin{array}{l}\text { Board size (pre-crisis) } \\
\text { Board expertise (pre- } \\
\text { crisis) } \\
\text { Board independence } \\
\text { (pre-crisis) } \\
\text { Board foreign (pre- } \\
\text { crisis) }\end{array}$ & & & & & $\begin{array}{r}11.101 \\
(9.92)\end{array}$ & $\begin{array}{r}25.632 * * \\
(11.87)\end{array}$ & $\begin{array}{r}-16.218 \\
(12.36)\end{array}$ & $\begin{array}{r}-0.941 \\
(17.47)\end{array}$ & & & \\
\hline $\begin{array}{l}\text { Risk management } \\
\text { index (pre-crisis) } \\
\text { Supervisory board } \\
\text { index (pre-crisis) }\end{array}$ & & & & & & & & & $\begin{array}{r}-5.786 \\
(10.40)\end{array}$ & $\begin{array}{c}-3.653 \\
(11.46)\end{array}$ & \\
\hline Foreign ownership & $\begin{array}{l}5.589 \\
(6.26)\end{array}$ & $\begin{array}{l}5.039 \\
(6.66)\end{array}$ & $\begin{array}{l}5.208 \\
(6.29)\end{array}$ & $\begin{array}{l}5.229 \\
(6.20)\end{array}$ & $\begin{array}{l}5.504 \\
(6.59)\end{array}$ & $\begin{array}{l}2.508 \\
(5.66)\end{array}$ & $\begin{array}{l}3.122 \\
(6.81)\end{array}$ & $\begin{array}{r}6.027 \\
(14.27)\end{array}$ & $\begin{array}{l}5.544 \\
(6.36)\end{array}$ & $\begin{array}{r}6.054 \\
(7.09)\end{array}$ & $\begin{array}{l}5.496 \\
(6.33)\end{array}$ \\
\hline Size of bank (pre-crisis) & $\begin{array}{l}-1.462 \\
(3.86)\end{array}$ & $\begin{array}{l}-2.001 \\
(3.91)\end{array}$ & $\begin{array}{r}-1.068 \\
(3.69)\end{array}$ & $\begin{array}{l}-1.309 \\
(3.77)\end{array}$ & $\begin{array}{l}-2.188 \\
(3.61)\end{array}$ & $\begin{array}{l}-2.025 \\
(3.80)\end{array}$ & $\begin{array}{r}-1.449 \\
(3.82)\end{array}$ & $\begin{array}{r}-1.461 \\
(3.50)\end{array}$ & $\begin{array}{r}-1.210 \\
(3.83)\end{array}$ & $\begin{array}{l}-1.428 \\
(3.74)\end{array}$ & $\begin{array}{l}-1.501 \\
(3.82)\end{array}$ \\
\hline $\begin{array}{l}\text { Capital structure - } \\
\text { Equity/TA (pre-crisis) }\end{array}$ & $\begin{array}{r}-0.289 \\
(0.59)\end{array}$ & $\begin{array}{r}-0.278 \\
(0.61)\end{array}$ & $\begin{array}{r}-0.203 \\
(0.54)\end{array}$ & $\begin{array}{r}-0.204 \\
(0.55)\end{array}$ & $\begin{array}{r}-0.262 \\
(0.57)\end{array}$ & $\begin{array}{r}-0.133 \\
(0.58)\end{array}$ & $\begin{array}{r}-0.262 \\
(0.58)\end{array}$ & $\begin{array}{r}-0.231 \\
(0.58)\end{array}$ & $\begin{array}{r}-0.222 \\
(0.56)\end{array}$ & $\begin{array}{r}-0.247 \\
(0.58)\end{array}$ & $\begin{array}{r}-0.231 \\
(0.57)\end{array}$ \\
\hline $\begin{array}{l}\text { Asset structure - } \\
\text { Loan/TA (pre-crisis) }\end{array}$ & $\begin{array}{r}34.276 \\
(22.13)\end{array}$ & $\begin{array}{l}35.241 \\
(22.93)\end{array}$ & $\begin{array}{r}34.519 \\
(21.91)\end{array}$ & $\begin{array}{r}35.533 \\
(22.31)\end{array}$ & $\begin{array}{l}35.578 \\
(23.86)\end{array}$ & $\begin{array}{r}31.849 \\
(19.98)\end{array}$ & $\begin{array}{l}31.108 \\
(22.04)\end{array}$ & $\begin{array}{r}34.469 \\
(20.35)\end{array}$ & $\begin{array}{r}34.385 \\
(22.20)\end{array}$ & $\begin{array}{l}34.657 \\
(22.11)\end{array}$ & $\begin{array}{l}34.308 \\
(22.38)\end{array}$ \\
\hline Constant & $\begin{array}{r}47.119 \\
(59.52)\end{array}$ & $\begin{array}{l}49.485 \\
(61.45)\end{array}$ & $\begin{array}{r}38.554 \\
(58.37)\end{array}$ & $\begin{array}{r}40.332 \\
(59.53)\end{array}$ & $\begin{array}{l}31.957 \\
(66.28)\end{array}$ & $\begin{array}{r}30.427 \\
(53.80)\end{array}$ & $\begin{array}{r}49.263 \\
(60.93)\end{array}$ & $\begin{array}{r}42.594 \\
(55.52)\end{array}$ & $\begin{array}{r}40.869 \\
(60.28)\end{array}$ & $\begin{array}{r}43.639 \\
(61.29)\end{array}$ & $\begin{array}{r}43.122 \\
(60.51)\end{array}$ \\
\hline Host country FE & YES & YES & YES & YES & YES & YES & YES & YES & YES & YES & YES \\
\hline R-squared & 0.065 & 0.053 & 0.035 & 0.045 & 0.037 & 0.075 & 0.079 & 0.050 & 0.051 & 0.053 & 0.053 \\
\hline N. of cases & 156 & 156 & 156 & 156 & 156 & 156 & 156 & 156 & 156 & 156 & 156 \\
\hline $\begin{array}{l}\text { Mean of dependent } \\
\text { variable }\end{array}$ & 43.68 & 43.68 & 43.68 & 43.68 & 43.68 & 43.68 & 43.68 & 43.68 & 43.68 & 43.68 & 43.68 \\
\hline
\end{tabular}


Table 4 Risk management and corporate governance and credit growth during the crisis period

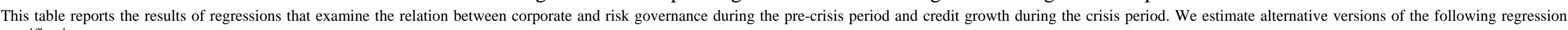
specification:

Credgr $_{i, c, 2009-2012}=\alpha_{c}+\beta \times$ Gov $_{i, 2005-2007}+\gamma \times$ Control $_{i, 2005-2007}+\varepsilon_{i, c}$

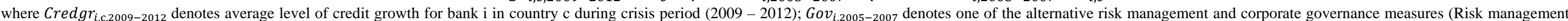

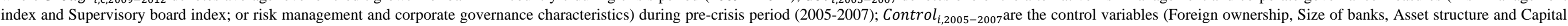

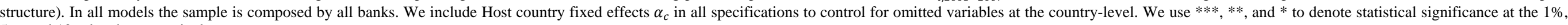
$5 \%$, and $10 \%$ levels, respectively.

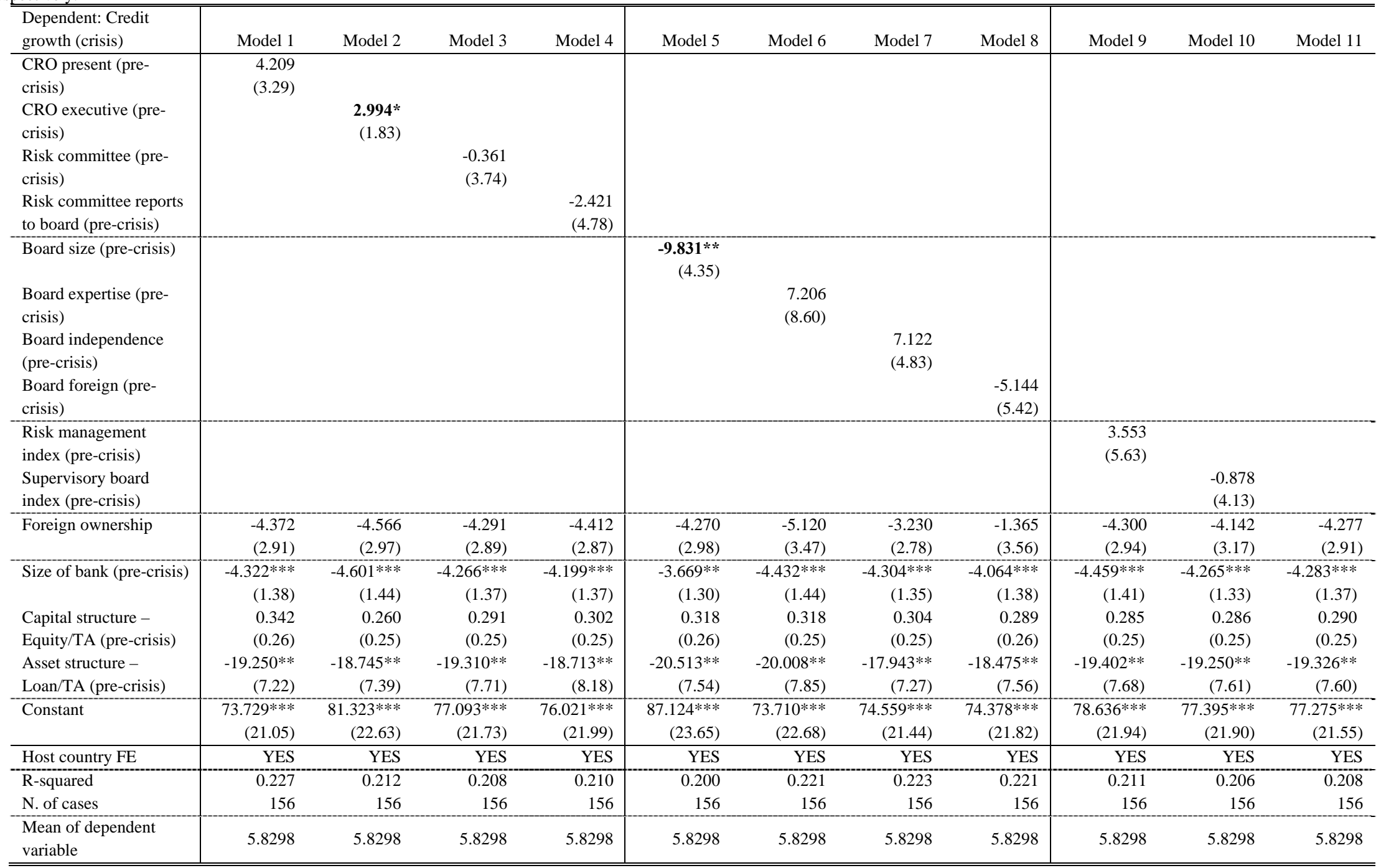


Table 5 Risk management and corporate governance and credit losses during the crisis period

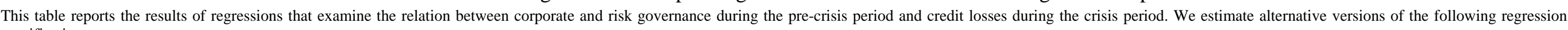
specification:

$N P L_{i, c, 2009-2012}=\alpha_{c}+\beta \times$ Gov $_{i, 2005-2007}+\gamma \times$ Control $_{i, 2005-2007}+\varepsilon_{i, c}$

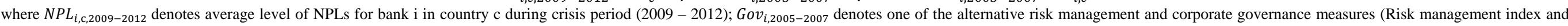

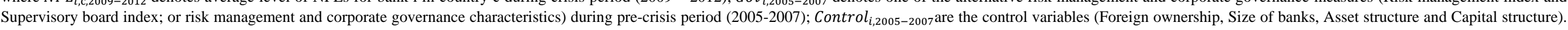

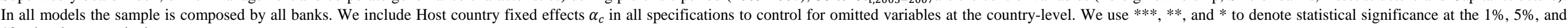
$10 \%$ levels, respectively.

\begin{tabular}{|c|c|c|c|c|c|c|c|c|c|c|c|}
\hline $\begin{array}{l}\text { Dependent: Credit } \\
\text { losses- NPLs (crisis) }\end{array}$ & Model 1 & Model 2 & Model 3 & Model 4 & Model 5 & Model 6 & Model 7 & Model 8 & Model 9 & Model 10 & Model 11 \\
\hline $\begin{array}{l}\text { CRO present (pre- } \\
\text { crisis) } \\
\text { CRO executive (pre- } \\
\text { crisis) } \\
\text { Risk committee (pre- } \\
\text { crisis) } \\
\text { Risk committee reports } \\
\text { to board (pre-crisis) }\end{array}$ & $\begin{array}{l}3.257 \\
(2.54)\end{array}$ & $\begin{array}{r}-2.304 \\
(1.67)\end{array}$ & $\begin{array}{l}3.440 \\
(2.58)\end{array}$ & $\begin{array}{r}\mathbf{5 . 3 5 5 *}^{*} \\
(3.25)\end{array}$ & & & & & & & \\
\hline $\begin{array}{l}\text { Board size (pre-crisis) } \\
\text { Board expertise (pre- } \\
\text { crisis) } \\
\text { Board independence } \\
\text { (pre-crisis) } \\
\text { Board foreign (pre- } \\
\text { crisis) }\end{array}$ & & & & & $\begin{array}{l}3.111 \\
(4.66)\end{array}$ & $\begin{array}{l}1.274 \\
(4.64)\end{array}$ & $\begin{array}{l}-4.867 \\
(3.20)\end{array}$ & $\begin{array}{r}-\mathbf{6 . 4 4 6 *} \\
(6.13)\end{array}$ & & & \\
\hline $\begin{array}{l}\text { Risk management } \\
\text { index (pre-crisis) } \\
\text { Supervisory board } \\
\text { index (pre-crisis) }\end{array}$ & & & & & & & & & $\begin{array}{l}4.401 \\
(3.52)\end{array}$ & $\begin{array}{l}-3.413 \\
(3.48)\end{array}$ & \\
\hline Foreign ownership & $\begin{array}{r}-1.540 \\
(2.56)\end{array}$ & $\begin{array}{l}-1.088 \\
(2.52)\end{array}$ & $\begin{array}{l}-1.227 \\
(2.65)\end{array}$ & $\begin{array}{r}-1.020 \\
(2.74)\end{array}$ & $\begin{array}{r}-1.347 \\
(2.53)\end{array}$ & $\begin{array}{l}-1.554 \\
(2.82)\end{array}$ & $\begin{array}{r}-2.199 \\
(2.40)\end{array}$ & $\begin{array}{l}2.482 \\
(5.66)\end{array}$ & $\begin{array}{r}-1.440 \\
(2.58)\end{array}$ & $\begin{array}{r}-0.767 \\
(2.91)\end{array}$ & $\begin{array}{r}-1.363 \\
(2.58)\end{array}$ \\
\hline $\begin{array}{l}\text { Size of bank (pre- } \\
\text { crisis) }\end{array}$ & $\begin{array}{r}-0.677 \\
(1.04)\end{array}$ & $\begin{array}{r}-0.386 \\
(1.13)\end{array}$ & $\begin{array}{r}-0.797 \\
(1.09)\end{array}$ & $\begin{array}{r}-0.838 \\
(1.10)\end{array}$ & $\begin{array}{l}-0.813 \\
(1.07)\end{array}$ & $\begin{array}{l}-0.650 \\
(1.07)\end{array}$ & $\begin{array}{r}-0.641 \\
(1.05)\end{array}$ & $\begin{array}{r}-0.395 \\
(0.93)\end{array}$ & $\begin{array}{r}-0.861 \\
(1.13)\end{array}$ & $\begin{array}{l}-0.593 \\
(1.05)\end{array}$ & $\begin{array}{l}-0.634 \\
(1.05)\end{array}$ \\
\hline $\begin{array}{l}\text { Capital structure - } \\
\text { Equity/TA (pre-crisis) }\end{array}$ & $\begin{array}{r}0.538^{* *} \\
(0.24)\end{array}$ & $\begin{array}{r}0.538^{*} \\
(0.25)\end{array}$ & $\begin{array}{r}0.506^{* *} \\
(0.23)\end{array}$ & $\begin{array}{r}0.487^{* *} \\
(0.23)\end{array}$ & $\begin{array}{r}0.510^{*} \\
(0.25)\end{array}$ & $\begin{array}{r}0.524 * * \\
(0.25)\end{array}$ & $\begin{array}{r}0.500 * \\
(0.26)\end{array}$ & $\begin{array}{r}0.507^{*} \\
(0.26)\end{array}$ & $\begin{array}{r}0.507^{* *} \\
(0.23)\end{array}$ & $\begin{array}{r}0.494^{*} \\
(0.27)\end{array}$ & $\begin{array}{r}0.521^{*} \\
(0.25)\end{array}$ \\
\hline $\begin{array}{l}\text { Asset structure - } \\
\text { Loan/TA (pre-crisis) }\end{array}$ & $\begin{array}{r}-6.052 \\
(8.09)\end{array}$ & $\begin{array}{r}-6.540 \\
(7.52)\end{array}$ & $\begin{array}{r}-6.096 \\
(7.62)\end{array}$ & $\begin{array}{r}-7.585 \\
(7.62)\end{array}$ & $\begin{array}{r}-5.553 \\
(6.84)\end{array}$ & $\begin{array}{r}-5.711 \\
(8.16)\end{array}$ & $\begin{array}{r}-6.582 \\
(7.79)\end{array}$ & $\begin{array}{r}-5.280 \\
(7.43)\end{array}$ & $\begin{array}{r}-6.037 \\
(7.86)\end{array}$ & $\begin{array}{l}-5.714 \\
(7.83)\end{array}$ & $\begin{array}{r}-5.870 \\
(7.79)\end{array}$ \\
\hline Constant & $\begin{array}{r}20.051 \\
(16.55)\end{array}$ & $\begin{array}{r}19.159 \\
(17.24)\end{array}$ & $\begin{array}{l}23.920 \\
(17.09)\end{array}$ & $\begin{array}{r}25.377 \\
(17.15)\end{array}$ & $\begin{array}{r}18.880 \\
(16.68)\end{array}$ & $\begin{array}{l}21.291 \\
(16.06)\end{array}$ & $\begin{array}{l}24.397 \\
(16.31)\end{array}$ & $\begin{array}{r}19.352 \\
(15.00)\end{array}$ & $\begin{array}{r}24.115 \\
(17.41)\end{array}$ & $\begin{array}{r}23.215 \\
(17.22)\end{array}$ & $\begin{array}{r}22.177 \\
(16.51)\end{array}$ \\
\hline Host country FE & YES & YES & YES & YES & YES & YES & YES & YES & YES & YES & YES \\
\hline $\begin{array}{l}\text { R-squared } \\
\text { N. of cases }\end{array}$ & $\begin{array}{r}0.063 \\
156\end{array}$ & $\begin{array}{r}0.066 \\
156\end{array}$ & $\begin{array}{r}0.073 \\
156\end{array}$ & $\begin{array}{r}0.073 \\
156\end{array}$ & $\begin{array}{r}0.049 \\
156\end{array}$ & $\begin{array}{r}0.065 \\
156\end{array}$ & $\begin{array}{r}0.090 \\
156\end{array}$ & $\begin{array}{r}0.045 \\
156\end{array}$ & $\begin{array}{r}0.067 \\
156\end{array}$ & $\begin{array}{r}0.076 \\
156\end{array}$ & $\begin{array}{r}0.063 \\
156\end{array}$ \\
\hline $\begin{array}{l}\text { Mean of dependent } \\
\text { variable }\end{array}$ & 14.34 & 14.34 & 14.34 & 14.34 & 14.34 & 14.34 & 14.34 & 14.34 & 14.34 & 14.34 & 14.34 \\
\hline
\end{tabular}


Table 6 Impact of credit losses on changes in risk management and corporate governance during the crisis

This table presents results for diff-in-diff analyses for the impact of credit losses on changes in Risk management index (RMI) and Supervisory board index (SBI) during the crisis. We estimate the following regression specification:

$$
\begin{aligned}
& \mathrm{RMI}_{\mathrm{i}, \mathrm{t}}=\beta_{0}+\beta_{1} \times \text { Crisis }_{t}+\beta_{2} \times \text { High_NPLs }_{i}+\beta_{3} \times \text { Crisis }_{t} \times \text { High_NPLs }_{i}+\beta_{\mathrm{k}} \times \mathrm{X}_{\mathrm{k}, \mathrm{i}, \mathrm{t}}+\varepsilon_{\mathrm{i}, \mathrm{t}} \\
& \mathrm{SBI}_{\mathrm{i}, \mathrm{t}}=\beta_{0}+\beta_{1} \times \text { Crisis }_{t}+\beta_{2} \times \text { High_NPLs }_{i}+\beta_{3} \times \text { Crisis }_{t} \times \text { High_NPLs }_{i}+\beta_{\mathrm{k}} \times \mathrm{X}_{\mathrm{k}, \mathrm{i}, \mathrm{t}}+\varepsilon_{\mathrm{i}, \mathrm{t}}
\end{aligned}
$$

where $R M I_{i, \mathrm{t}} / S B I_{i, \mathrm{t}}$ is the Risk management index/ Supervisory board index of bank i during year t, $\mathrm{t}=2007$ and 2012 ; Crisis is a dummy variable taking a one if the year is 2012; High_NPLs is a dummy variable taking a one if the bank has recorded an average level of NPLs during the period 2008-2010 greater than the median value of average NPLs for entire group of banks; $X_{k, i}$ are the control variables (Size of banks; Asset structure; Capital structure and Precrisis credit growth). In all models the sample is composed by all banks. Means and Standard Errors are estimated by linear regression; Clustered Std. Errors; Inference: *** $\mathrm{p}<0.01 ; * * \mathrm{p}<0.05 ;{ }^{*} \mathrm{p}<0.1$

\begin{tabular}{l|ccc|ccc}
\hline \hline & RMI (2007) & RMI (2012) & Diff. & SBI (2007) & SBI (2012) & Diff. \\
\hline All banks & 0.405 & 0.580 & $-0.174 * * *$ & 0.567 & 0.583 & -0.016 \\
\hline High NPLs (2008-2010) & 0.408 & 0.544 & $\mathbf{0 . 1 3 6 * * *}$ & 0.556 & 0.553 & $\mathbf{- 0 . 0 0 3}$ \\
Low NPLs (2008-2010) & 0.402 & 0.629 & $\mathbf{0 . 2 2 7 * * *}$ & 0.583 & 0.625 & $\mathbf{0 . 0 4 2}$ \\
\hline Diff & $\mathbf{0 . 0 0 7}$ & $\mathbf{- 0 . 0 8 4 * *}$ & $\mathbf{- 0 . 0 9 1 * *}$ & $\mathbf{- 0 . 0 2 8}$ & $\mathbf{- 0 . 0 7 2}$ & $\mathbf{- 0 . 0 4 4}$ \\
\hline Treated group (\# banks) & 90 & 90 & & 90 & 60 \\
Control group (\# banks) & 66 & 66 & & 66 & 66 \\
\hline \hline
\end{tabular}




\section{APPENDICES}

\section{Appendix 1 List of banks}

\begin{tabular}{|c|c|c|c|c|c|c|}
\hline Bank name & $\begin{array}{c}\text { Bank code } \\
\text { (BankScope) }\end{array}$ & $\begin{array}{c}\text { Total assets } \\
\text { (2012 - } \\
\text { Th. EUR) } \\
\end{array}$ & Host country & Ownership & $\begin{array}{l}\text { Home } \\
\text { country }\end{array}$ & $\begin{array}{c}\text { Member of } \\
\text { International } \\
\text { Banking Group } \\
\end{array}$ \\
\hline Intesa Sanpaolo Bank Albania & 17264 & 930331.09 & Albania & Foreign & Italy & Yes \\
\hline Commercial Bank & 17265 & 1771439.7 & Albania & Foreign & Turkey & No \\
\hline Tirana Bank SA-Banka e Tiranes Sha & 17266 & 698008.41 & Albania & Foreign & Greece & Yes \\
\hline Credit Agricole Bank (Albania) & 40598 & 232425.07 & Albania & Foreign & France & Yes \\
\hline Credins Bank Sh.A & 40932 & 657476.33 & Albania & Domestic & & No \\
\hline Raiffeisenbank d.d. Bosnia and Herzegovina & 10286 & 1884013.5 & Bosnia and Herzegovina & Foreign & Austria & Yes \\
\hline Hypo Alpe-Adria-Bank a.d., Mostar & 16550 & 944230.55 & Bosnia and Herzegovina & Foreign & Austria & Yes \\
\hline Hypo Alpe-Adria-Bank a.d. Banja Luka & 29065 & 715311.61 & Bosnia and Herzegovina & Foreign & Austria & Yes \\
\hline NLB Banka d.d. & 45854 & 404002.03 & Bosnia and Herzegovina & Foreign & Slovenia & Yes \\
\hline UniCredit Bank dd & 46705 & 1914280.4 & Bosnia and Herzegovina & Foreign & Italy & Yes \\
\hline Intesa Sanpaolo Banka d.d. Bosna i Hercegovina & 46742 & 677629.81 & Bosnia and Herzegovina & Foreign & Italy & Yes \\
\hline Sparkasse Bank dd & 40547 & 458758.57 & Bosnia and Herzegovina & Foreign & Austria & Yes \\
\hline Corporate Commercial Bank AD & 15330 & 2879110.8 & Bulgaria & Domestic & & No \\
\hline Eurobank Bulgaria AD-Postbank & 27290 & 2879775 & Bulgaria & Foreign & Greece & Yes \\
\hline Raiffeisenbank (Bulgaria) EAD & 27970 & 3152876.4 & Bulgaria & Foreign & Austria & Yes \\
\hline UniCredit Bulbank AD & 31014 & 6505342.8 & Bulgaria & Foreign & Italy & Yes \\
\hline United Bulgarian Bank - UBB & 37860 & 3243041.8 & Bulgaria & Foreign & Greece & Yes \\
\hline Societe Generale Expressbank & 43048 & 1944864.7 & Bulgaria & Foreign & France & Yes \\
\hline First Investment Bank AD & 43151 & 3601711 & Bulgaria & Domestic & & No \\
\hline Piraeus Bank Bulgaria AD & 46992 & 1582926 & Bulgaria & Foreign & Greece & Yes \\
\hline DSK Bank Plc & 48221 & 4445996.1. & Bulgaria & Foreign & Hungary & No \\
\hline Sberbank dd & 17113 & 1086652.5 & Croatia & Foreign & Russia & Yes \\
\hline OTP banka Hrvatska dd & 19951 & 1760686.9 & Croatia & Foreign & Hungary & Yes \\
\hline $\begin{array}{l}\text { Hrvatska Postanska Bank DD } \\
\text { Privredna Banka Zagreb d.d-Privredna Banka Zagreb }\end{array}$ & 27044 & 2255847.1 & Croatia & Domestic & & No \\
\hline Group & 31139 & 9601990.4 & Croatia & Foreign & Italy & Yes \\
\hline Zagrebacka Banka dd & 33081 & 15987127 & Croatia & Foreign & Italy & Yes \\
\hline Erste \& Steierm\%orkische Bank dd & 31492 & 8720191.2 & Croatia & Foreign & Austria & Yes \\
\hline Raiffeisenbank Austria d.d., Zagreb & 44997 & 5110147.7 & Croatia & Foreign & Austria & Yes \\
\hline Podravska Banka & 47433 & 404730.37 & Croatia & Domestic & & No \\
\hline Jadranska Banka dd & 47953 & 405405.32 & Croatia & Domestic & & No \\
\hline Hypo Alpe-Adria-Bank dd & 48157 & 4687802.5 & Croatia & Foreign & Austria & Yes \\
\hline Ceskomoravska Stavebni Sporitelna as-CMSS as & 16287 & 6707930.5 & Czech Republic & Foreign & Belgium & Yes \\
\hline Raiffeisen stavebnÌ sporitelna AS & 17601 & 3326765.6 & Czech Republic & Foreign & Austria & Yes \\
\hline Hypotecni banka a.s. & 17683 & 8001642.6 & Czech Republic & Foreign & Belgium & Yes \\
\hline J\&T Banka as & 18607 & 3516103.4 & Czech Republic & Foreign & Slovakia & No \\
\hline LBBW Bank CZ a.s & 38548 & 1195195.1 & Czech Republic & Foreign & Germany & No \\
\hline Unicredit Bank Czech Republic AS & 46381 & 12684395 & Czech Republic & Foreign & Italy & Yes \\
\hline Ceskoslovenska Obchodni Banka A.S.- CSOB & 30747 & 37275477 & Czech Republic & Foreign & Belgium & Yes \\
\hline Ceska Sporitelna a.s. & 33189 & 36608422 & Czech Republic & Foreign & Austria & Yes \\
\hline Komercni Banka & 42320 & 31295883 & Czech Republic & Foreign & France & Yes \\
\hline Raiffeisenbank akciova spolecnost & 43987 & 7857751 & Czech Republic & Foreign & Austria & Yes \\
\hline PPF banka a.s. & 46887 & 3065185.6 & Czech Republic & Domestic & & No \\
\hline
\end{tabular}




\begin{tabular}{|c|c|c|c|c|c|c|}
\hline Tallinn Business Bank Ltd-Tallinna fripanga AS & 19162 & 143676 & Estonia & Domestic & & No \\
\hline AS LHV Pank & 23803 & 311500 & Estonia & Domestic & & No \\
\hline BIGBANK AS & 27257 & 280729 & Estonia & Domestic & & No \\
\hline Estonian Credit Bank-Eesti Krediidipank & 38516 & 307149 & Estonia & Foreign & Latvia & No \\
\hline Versobank AS & 40442 & 62142 & Estonia & Foreign & Ukraine & No \\
\hline SEB Pank & 36731 & 4183000 & Estonia & Foreign & Sweden & Yes \\
\hline Swedbank As & 45119 & 8961000 & Estonia & Foreign & Sweden & Yes \\
\hline FHB Mortgage Bank Plc-FHB Jelzalogbank Nyrt. & 18740 & 2581878.8 & Hungary & Domestic & & No \\
\hline $\begin{array}{l}\text { UniCredit Bank Hungary Zrt } \\
\text { Budapest Bank Nyrt-Budapest Hitel-Ès FejleszÈsi }\end{array}$ & 33844 & 5685745.7 & Hungary & Foreign & Italy & Yes \\
\hline Bank Nyrt & 35605 & 3175300.1 & Hungary & Foreign & USA & Yes \\
\hline CIB Bank Ltd-CIB Bank Zrt & 37332 & 7270213.9 & Hungary & Foreign & Italy & Yes \\
\hline MKB Bank Zrt & 44318 & 8847848.7 & Hungary & Foreign & Germany & No \\
\hline Raiffeisen Bank Zrt & 33925 & 7207597.1 & Hungary & Foreign & Austria & Yes \\
\hline K\&H Bank Zrt & 33965 & 8446552.4 & Hungary & Foreign & Belgium & Yes \\
\hline OTP Bank Plc & 44850 & 34694228 & Hungary & Domestic & & Yes \\
\hline Erste Bank Hungary Nyrt & 48242 & 9564915.4 & Hungary & Foreign & Austria & Yes \\
\hline Norvik Banka & 26760 & 752761.71 & Latvia & Foreign & Russia & No \\
\hline AS DNB Banka & 33110 & 2354628.4 & Latvia & Foreign & Norway & Yes \\
\hline UniCredit Bank AS & 46489 & 819987.87 & Latvia & Foreign & Italy & Yes \\
\hline As PrivatBank & 48983 & 766463.86 & Latvia & Foreign & Ukraine & No \\
\hline Swedbank AS & 32949 & 4912219.8 & Latvia & Foreign & Sweden & Yes \\
\hline Rietumu Bank Group-Rietumu Banka & 44200 & 2355199.3 & Latvia & Domestic & & No \\
\hline Trasta Komercbanka-Trust Commercial Bank & 45023 & 434186.79 & Latvia & Domestic & & No \\
\hline ABLV Bank AS & 45088 & 3039022.1 & Latvia & Domestic & & No \\
\hline $\begin{array}{l}\text { SEB banka AS } \\
\text { Mortgage and Land Bank of Latvia-Latvijas Hipoteku } \\
\text { un zemes banka }\end{array}$ & 46622 & $\begin{array}{r}3955067.7 \\
514544.17 \\
\end{array}$ & $\begin{array}{l}\text { Latvia } \\
\text { Latvia }\end{array}$ & $\begin{array}{r}\text { Foreign } \\
\text { Domestic }\end{array}$ & Sweden & Yes \\
\hline AB DNB Bankas & 38058 & 3351977.1 & Lithuania & Foreign & Norway & Yes \\
\hline Citadele Bankas AB & 45043 & 313397.18 & Lithuania & Foreign & Latvia & No \\
\hline Siauliu Bankas & 38681 & 855822.08 & Lithuania & Domestic & & No \\
\hline Swedbank AB & 46673 & 5642196.2 & Lithuania & Foreign & Sweden & Yes \\
\hline UAB Medicinos Bankas & 47638 & 253428.27 & Lithuania & Domestic & & No \\
\hline Halk Banka AD Skopje & 19934 & 294783.48 & Macedonia (FYROM) & Foreign & Turkey & No \\
\hline TTK Banka AD Skopje & 25280 & 111687.54 & Macedonia (FYROM) & Domestic & & No \\
\hline ProCredit Bank AD & 40920 & 245245.66 & Macedonia (FYROM) & Foreign & Germany & Yes \\
\hline NLB Tutunska Banka A.D. Skopje & 44793 & 968502.35 & Macedonia (FYROM) & Foreign & Slovenia & Yes \\
\hline Stopanska Banka a.d. Skopje & 30961 & 1233620.3 & Macedonia (FYROM) & Foreign & Greece & Yes \\
\hline Komercijalna Banka A.D. Skopje & 35919 & 1344781.5 & Macedonia (FYROM) & Domestic & & No \\
\hline Alpha Bank AD Skopje & 37938 & 107344.93 & Macedonia (FYROM) & Foreign & Greece & Yes \\
\hline Sparkasse Bank Makedonija A.D. & 42980 & 240591.99 & Macedonia (FYROM) & Foreign & Austria & Yes \\
\hline Stopanska Banka AD, Bitola & 45348 & 120470.52 & Macedonia (FYROM) & Domestic & & No \\
\hline $\begin{array}{l}\text { Ohridska Banka ad Ohrid } \\
\text { Macedonian Bank for Development Promotion ad- } \\
\text { Makedonska banka za poddrshka na razvojot AD }\end{array}$ & 46717 & $\begin{array}{r}437907.35 \\
199436.34 \\
\end{array}$ & $\begin{array}{l}\text { Macedonia (FYROM) } \\
\text { Macedonia (FYROM) }\end{array}$ & $\begin{array}{r}\text { Foreign } \\
\text { Domestic }\end{array}$ & France & Yes \\
\hline $\begin{array}{l}\text { Crnogorsko Komercijalna Banka AD Podgorica-CKB } \\
\text { Bank }\end{array}$ & 19075 & 673700 & Montenegro & Foreign & Hungary & Yes \\
\hline NLB Montenegrobanka ad Podgorica & 27968 & 476202 & Montenegro & Foreign & Slovenia & Yes \\
\hline Hipotekarna Banka ad Podgorica & 28971 & 173800 & Montenegro & Domestic & & No \\
\hline Societe Generale Banka Montenegro AD & 29075 & 312200 & Montenegro & Foreign & France & Yes \\
\hline Komercijalna Banka AD Budva & 40824 & 96600 & Montenegro & Foreign & Serbia & No \\
\hline Erste Bank AD Podgorica & 40803 & 348700 & Montenegro & Foreign & Austria & Yes \\
\hline
\end{tabular}




\begin{tabular}{|c|c|c|c|c|c|c|}
\hline BNP Paribas Bank Polska SA & 11560 & 4705870.5 & Poland & Foreign & France & Yes \\
\hline Bank Handlowy w Warszawie S.A. & 30746 & 10638573 & Poland & Foreign & USA & Yes \\
\hline Bank Polska Kasa Opieki SA-Bank Pekao SA & 31008 & 36909555 & Poland & Foreign & Italy & Yes \\
\hline Bank BPH SA & 31077 & 8415340.7 & Poland & Foreign & USA & Yes \\
\hline Bank Zachodni WBK S.A. & 32473 & 14675620 & Poland & Foreign & Spain & Yes \\
\hline BRE Bank SA & 33964 & 24998279 & Poland & Foreign & Germany & Yes \\
\hline Bank Millennium & 45307 & 12896355 & Poland & Foreign & Portugal & Yes \\
\hline ING Bank Slaski S.A. - Capital Group & 48129 & 19137440 & Poland & Foreign & Netherlands & Yes \\
\hline $\begin{array}{l}\text { Powszechna Kasa Uszczednoscı Bank Polskı SA - } \\
\text { PKO BP SA }\end{array}$ & 33088 & 47308747 & Poland & Domestic & & No \\
\hline Raiffeisen Bank Polska SA & 35083 & 13371302 & Poland & Foreign & Austria & Yes \\
\hline Kredyt Bank SA & 48171 & 10015058 & Poland & Foreign & Belgium & Yes \\
\hline Nordea Bank Polska SA & 48321 & 8144857.7 & Poland & Foreign & Sweden & Yes \\
\hline Alpha Bank Romani & 10204 & 3721847.8 & Romania & Foreign & Greece & Yes \\
\hline Intesa Sanpaolo Bank Romania SA & 10205 & 1143497.9 & Romania & Foreign & Italy & Yes \\
\hline Volksbank Romania & 18847 & 3715685.3 & Romania & Foreign & Austria & Yes \\
\hline Raiffeisen Bank SA & 19835 & 5422636.4 & Romania & Foreign & Austria & Yes \\
\hline UniCredit Tiriac Bank SA & 36496 & 5655390.2 & Romania & Foreign & Italy & Yes \\
\hline $\begin{array}{l}\text { BRD-Groupe Societe Generale SA } \\
\text { Banca Comerciala Romana SA-Romanian }\end{array}$ & 36742 & 11036243 & Romania & Foreign & France & Yes \\
\hline $\begin{array}{l}\text { Banca Comerciala Romana SA-Romanıan } \\
\text { Commercial Bank SA }\end{array}$ & 38557 & 16543462 & Romania & Foreign & Austria & Yes \\
\hline Bancpost SA & 38558 & 2750471.7 & Romania & Foreign & Greece & Yes \\
\hline CEC Bank SA & 38559 & 6073132.5 & Romania & Domestic & & No \\
\hline Piraeus Bank Romania & 44695 & 2246531.1 & Romania & Foreign & Greece & Yes \\
\hline Transilvania Bank-Banca Transilvania SA & 44741 & 6706811.4 & Romania & Domestic & & No \\
\hline OTP Bank Romania SA & 46731 & 1047312.9 & Romania & Foreign & Hungary & Yes \\
\hline Komercijalna Banka A.D. Beograd & 12565 & 2851154.4 & Serbia & Domestic & & Yes \\
\hline Societe Generale Banka Srbija ad & 12890 & 1784678.7 & Serbia & Foreign & France & Yes \\
\hline AIK Banka ad Nis & 16829 & 1357491.7 & Serbia & Domestic & & No \\
\hline UniCredit Bank Serbia JSC-UniCredit Bank Srbija a.d & 40493 & 2142396.9 & Serbia & Foreign & Italy & Yes \\
\hline Banca Intesa ad Beograd & 46134 & 3635135.2 & Serbia & Foreign & Italy & Yes \\
\hline Vojvodjanska Banka A.D., Novi Sad & 31338 & 915216.3 & Serbia & Foreign & Greece & Yes \\
\hline Hypo Alpe-Adria-Bank AD Beograd & 40215 & 1481742.3 & Serbia & Foreign & Austria & Yes \\
\hline Eurobank EFG Stedionica AD Beograd & 40823 & 1707590 & Serbia & Foreign & Greece & Yes \\
\hline Erste Bank a.d. Novi Sad & 44815 & 709651.94 & Serbia & Foreign & Austria & Yes \\
\hline Alpha Bank Srbija AD & 47051 & 802398.85 & Serbia & Foreign & Greece & Yes \\
\hline UniCredit Bank Slovakia a.s. & 12393 & 4027100 & Slovakia & Foreign & Italy & Yes \\
\hline Post Bank JSC-Postova Banka, A.S. & 15627 & 3427700 & Slovakia & Domestic & & No \\
\hline Vseobecna Uverova Banka a.s. & 35884 & 11216000 & Slovakia & Foreign & Italy & Yes \\
\hline Sberbank Slovensko, as & 42553 & 1748400 & Slovakia & Foreign & Russia & Yes \\
\hline Slovenska sporitel'na as-Slovak Savings Bank & 35909 & 11777300 & Slovakia & Foreign & Austria & Yes \\
\hline Tatra Banka a.s. & 37500 & 9073000 & Slovakia & Foreign & Austria & Yes \\
\hline OTP Banka Slovensko, as & 38552 & 1270700 & Slovakia & Foreign & Hungary & Yes \\
\hline Prima banka Slovensko a.s. & 44132 & 1979400 & Slovakia & Domestic & & No \\
\hline $\begin{array}{l}\text { Komercni Banka Bratislava a.s. } \\
\text { Prva Stavebna Sporitelna as-First Building Savings }\end{array}$ & 45000 & 184800 & Slovakia & Foreign & France & Yes \\
\hline Bank & 49408 & 2285200 & Slovakia & Foreign & Austria & No \\
\hline
\end{tabular}




\begin{tabular}{|c|c|c|c|c|c|c|}
\hline Banka Sparkasse dd & 13045 & 1103218 & Slovenia & Foreign & Austria & Yes \\
\hline Hypo Alpe-Adria-Bank dd & 16598 & 1900800 & Slovenia & Foreign & Austria & Yes \\
\hline UniCredit Banka Slovenija d.d. & 37985 & 2815400 & Slovenia & Foreign & Italy & Yes \\
\hline Banka Koper d.d. & 48179 & 2375400 & Slovenia & Foreign & Italy & Yes \\
\hline Nova Kreditna Banka Maribor d.d. & 31186 & 5321800 & Slovenia & Domestic & & No \\
\hline NLB dd-Nova Ljubljanska Banka d.d. & 31238 & 14334700 & Slovenia & Domestic & & Yes \\
\hline Abanka Vipa dd & 35837 & 3614000 & Slovenia & Domestic & & No \\
\hline SKB Banka DD & 35960 & 2732300 & Slovenia & Foreign & France & Yes \\
\hline Banka Celje dd & 37657 & 2271400 & Slovenia & Domestic & & Yes \\
\hline Gorenjska Banka d.d. Kranj & 38653 & 1790000 & Slovenia & Domestic & & No \\
\hline Raiffeisen Banka dd & 46657 & 1420300 & Slovenia & Foreign & Austria & Yes \\
\hline Credit Agricole Bank PJSC & 16559 & 249326 & Ukraine & Foreign & France & Yes \\
\hline $\begin{array}{l}\text { OTP Bank } \\
\text { Joint-Stock Commercial Bank for Social }\end{array}$ & 17141 & 2043570.7 & Ukraine & Foreign & Hungary & Yes \\
\hline $\begin{array}{l}\text { Development - Ukrsotsbank } \\
\text { Closed Joint-Stock Company Subsidiary Bank }\end{array}$ & 46068 & 3815774.7 & Ukraine & Foreign & Italy & Yes \\
\hline Sberbank of Russia & 50387 & 2499922.6 & Ukraine & Foreign & Russia & Yes \\
\hline JSIB UkrSibbank & 38483 & 2392547.9 & Ukraine & Foreign & France & Yes \\
\hline PrivatBank & 44922 & 15762670 & Ukraine & Domestic & & Yes \\
\hline Pivdennyi Joint-Stock Bank & 46565 & 1280398.7 & Ukraine & Domestic & & No \\
\hline Raiffeisen Bank Aval & 46840 & 4855054.4 & Ukraine & Foreign & Austria & Yes \\
\hline $\begin{array}{l}\text { First Ukrainian International Bank } \\
\text { Oschadny Bank Ukrainy - Oschadbank-State Savings }\end{array}$ & 50295 & 2612784.5 & Ukraine & Domestic & & No \\
\hline Bank of Ukraine JSC & 50319 & 7909525 & Ukraine & Domestic & & No \\
\hline Ukrgasbank & 50407 & 1747266.2 & Ukraine & Domestic & & No \\
\hline
\end{tabular}


Appendix 2 Definition of all variables

\begin{tabular}{|c|c|c|}
\hline Variable & Definition & Source \\
\hline Credit growth & Annual Growth of Gross Loans (\%) & Bureau van Dijk - BankScope \\
\hline NPLs & Impaired Loans(NPLs)/ Gross Loans (\%) & Bureau van Dijk - BankScope \\
\hline Credit drop & Average pre-crisis Credit growth - Average crisis Credit growth & Bureau van Dijk - BankScope \\
\hline $\begin{array}{l}\text { Risk management } \\
\text { index }\end{array}$ & $\begin{array}{l}\text { Risk management index (RMI) is an unweighted average index of } 4 \text { indicators ( CRO present, CRO executive, } \\
\text { Risk committee; and Risk committee reports to board) that could take values between } 0 \text { and } 1 \text {, with } 1 \text { representing } \\
\text { a tight risk management structure. }\end{array}$ & $\begin{array}{l}\text { Annual Reports, Financial Statements, } \\
\text { Capital adequacy and risk management } \\
\text { reports and websites of banks }\end{array}$ \\
\hline $\begin{array}{l}\text { Supervisory board } \\
\text { index }\end{array}$ & $\begin{array}{l}\text { Supervisory board index (SBI) is an unweighted average index of } 4 \text { indicators (Boar size, Board expertise; Board } \\
\text { independence; and Board foreign) that could take values between } 0 \text { and } 1 \text {, with } 1 \text { representing a tight supervisory } \\
\text { board index. }\end{array}$ & $\begin{array}{l}\text { Annual Reports, Financial Statements, } \\
\text { Capital adequacy and risk management } \\
\text { reports and websites of banks }\end{array}$ \\
\hline CRO present & $\begin{array}{l}\text { CRO Present is a dummy variable that identifies whether a Chief Risk Officer (or an equivalent function - Deputy } \\
\text { CEO -Risk, Executive Vice-president Risk; Chief Strategy and Risk Officer, Chief Credit and Risk Officer, Chief } \\
\text { Lending and Risk Officer; Global Risk Executive, Director of Risk Management, Chief Risk Manager; Vice- } \\
\text { president - Risk Division; Executive Vice-president Risk; or Risk Management Officer) responsible for bank-wide } \\
\text { risk management is present within the bank. }\end{array}$ & $\begin{array}{l}\text { Annual Reports, Financial Statements, } \\
\text { Capital adequacy and risk management } \\
\text { reports and websites of banks }\end{array}$ \\
\hline CRO executive & CRO Executive - a dummy variable that identifies whether the CRO is an executive officer of the bank. & $\begin{array}{l}\text { Annual Reports, Financial Statements, } \\
\text { Capital adequacy and risk management } \\
\text { reports and websites of banks }\end{array}$ \\
\hline Risk committee & $\begin{array}{l}\text { Risk committee - a dummy variable that is equal to one if the bank has a dedicated committee solely charged with } \\
\text { monitoring and managing the risk management efforts within the bank. }\end{array}$ & $\begin{array}{l}\text { Annual Reports, Financial Statements, } \\
\text { Capital adequacy and risk management } \\
\text { reports and websites of banks }\end{array}$ \\
\hline $\begin{array}{l}\text { Risk committee } \\
\text { reports to board }\end{array}$ & $\begin{array}{l}\text { Reports to board - a dummy variable that identifies whether the key management-level risk committee reports } \\
\text { directly to the bank's board of directors. }\end{array}$ & $\begin{array}{l}\text { Annual Reports, Financial Statements, } \\
\text { Capital adequacy and risk management } \\
\text { reports and websites of banks }\end{array}$ \\
\hline Board size & The variable Board size is measured as the natural logarithm of the number of directors on a bank's board. & $\begin{array}{l}\text { Annual Reports, Financial Statements, } \\
\text { Capital adequacy and risk management } \\
\text { reports and websites of banks }\end{array}$ \\
\hline Board expertise & $\begin{array}{l}\text { The variable Board expertise is measured by the percentage of expert members on the board. Similar to Güner et } \\
\text { al. (2008) and Minton et al. (2014), we classify an member of supervisory board as an expert if he or she (i) has } \\
\text { worked within a banking institution, (ii) currently works at a non-bank financial institution, (iii) has a finance- } \\
\text { related role within a non-financial firm (e.g. CFO, accountant, treasurer, or VP finance) or (iv) academic } \\
\text { institution (e.g. professor in finance, accounting, economics, business or financial law), (v) has economic studies } \\
\text { background. }\end{array}$ & $\begin{array}{l}\text { Annual Reports, Financial Statements, } \\
\text { Capital adequacy and risk management } \\
\text { reports and websites of banks }\end{array}$ \\
\hline Board independence & $\begin{array}{l}\text { Board independence - measured by the percentage of independent outside directors on the supervisory board. } \\
\text { Following Aebi et al. (2012), we define independent members of board as members without any relation with the } \\
\text { company except for their board seat. }\end{array}$ & $\begin{array}{l}\text { Annual Reports, Financial Statements, } \\
\text { Capital adequacy and risk management } \\
\text { reports and websites of banks }\end{array}$ \\
\hline Board foreign & Board foreign is the percentage of members with foreign nationality on the supervisory board. & $\begin{array}{l}\text { Annual Reports, Financial Statements, } \\
\text { Capital adequacy and risk management } \\
\text { reports and websites of banks }\end{array}$ \\
\hline Size of bank & Size of bank is measured by the logarithm of the bank’s total assets. & Bureau van Dijk - BankScope \\
\hline Asset structure & $\begin{array}{l}\text { Asset structure is an indicator that reflects the banks' investment strategy equal to the ratio of Loans to Total } \\
\text { assets. }\end{array}$ & Bureau van Dijk - BankScope \\
\hline Capital structure & Capital structure is an indicator defined as regulatory capital divided by total assets & Bureau van Dijk - BankScope \\
\hline
\end{tabular}

Official supervisory power index is based on the following questions that are relevant to internal governance structure: 1 . Does the supervisory agency have the right to meet external auditors to discuss their report without the approval of the bank? 2. Are auditors required by law to communicate directly to the supervisory agency any presumed involvement of bank directors or senior managers in illicit activities, fraud or insider abuse? 3. Can the supervisory authority force a bank to change its internal organisational structure? 4. Has this power been utilised in the last 5 years? 5 . Can the supervisory agency order the bank's directors or management to establish provisions to cover actual or potential losses? 6. Can the supervisory agency suspend the directors' decision to distribute dividends? It sums up the 6 dummies and ranges from 1 (low power) to 6 (high power). Higher values indicate greater official supervisory power.

Capital Regulatory Index is based on the following questions: 1. Is the minimum capital-asset ratio requirement risk-weighted in line with the Basel I guidelines? 2. Does the minimum ratio vary as a function of an individual bank's credit risk? 3. Does the minimum ratio vary as a function of market risk? 4 . Is the market value of loan losses not realised in accounting books deducted from the book value of capital before minimum capital adequacy Capital Regulatory $\quad$ is determined? 5. Are unrealised losses in securities portfolios deducted? 6. Are unrealised foreign exchange losses deducted? 7. Is the fraction of revaluation gains which is allowed as part of capital less than 0.75 ? 8 . Are the sources of funds to be used as capital verified by the regulatory/supervisory authorities? 9. Can the initial disbursement or subsequent injections of capital be carried out with assets other than cash or government securities? 10. Can the initial disbursement of capital be carried out with borrowed funds? It ranges from 3 (low capital stringency) to 10 (high capital stringency). Higher values indicate greater capital stringency.

Restrictions on Banking Activities index measure the extent to which banks may engage in securities (underwriting, brokering, dealing and all aspects of the mutual fund industry), insurance (insurance underwriting and selling) and real estate (real estate investment, development and management) activities. In each case of securities, insurance or real estate activity, Unrestricted $=1=$ full range of activities can be conducted directly in the bank; Permitted = 2 = full range of activities can be conducted, but some or all must be conducted in subsidiaries; Restricted = 3 = less than a full range of activities can be conducted in the bank or subsidiaries; and Prohibited $=4=$ the activity cannot be conducted in either the bank or its subsidiaries. The overall activities restrictiveness index is the sum of restriction on the three activities. It ranges from 3 (low restrictiveness) to 12 (high restrictiveness). High values indicate greater restriction.

Restrictions on Banking Activities index
Regulatory Index construct as a normalized unweighted average index of three regulation and supervision indicators: Restrictions on Banking Activities Index, Capital Regulatory Index, Official Supervisory Power index)
Bureau van Dijk - BankScope reports and websites of banks

Reports, Financial Statements, Capital adequacy and risk management Corts and websites of banks Capital adequacy and risk management ites of banks Reports, Financial Statements, y and risk management reports and websites of banks

Annual Reports, Financial Statements, Capital adequacy and risk management reports and websites of banks

Annual Reports, Financial Statements, Capital adequacy and risk management

Annual Reports, Financial Statements, Capital adequacy and risk management Corts and websites of banks

Capital adequacy and risk management reports and websites of banks

- BankScope

Bureau van Dijk - BankScope

World Bank Survey of Bank Regulation and Supervision, 2003, 2007 and 2011.

World Bank Survey of Bank Regulation and Supervision, 2003, 2007 and 2011.

World Bank Survey of Bank Regulation and Supervision, 2003, 2007 and 2011.

World Bank Survey of Bank Regulation and Supervision, 2003, 2007 and 2011. 
Appendix 3 Correlation matrix

\begin{tabular}{|c|c|c|c|c|c|c|c|c|c|c|c|c|c|}
\hline & $\begin{array}{l}\text { Credit growth } \\
\text { (pre-crisis) }\end{array}$ & $\begin{array}{l}\text { Credit drop } \\
\quad \text { (crisis) }\end{array}$ & $\begin{array}{l}\text { Credit growth } \\
\text { (crisis) }\end{array}$ & $\begin{array}{l}\text { NPLs } \\
\text { (crisis) }\end{array}$ & $\begin{array}{l}\text { CRO present } \\
\text { (pre-crisis) }\end{array}$ & $\begin{array}{c}\text { CRO } \\
\text { executive } \\
\text { (pre-crisis) }\end{array}$ & $\begin{array}{c}\text { Risk } \\
\text { committee } \\
\text { (pre-crisis) }\end{array}$ & $\begin{array}{c}\text { Risk } \\
\text { committee } \\
\text { reports to } \\
\text { board } \\
\text { (pre-crisis) }\end{array}$ & $\begin{array}{l}\text { Board size } \\
\text { (pre-crisis) }\end{array}$ & $\begin{array}{c}\text { Board } \\
\text { expertise } \\
\text { (pre-crisis) }\end{array}$ & $\begin{array}{c}\text { Board } \\
\text { independence } \\
\text { (pre-crisis) }\end{array}$ & $\begin{array}{l}\text { Board foreign } \\
\text { (pre-crisis) }\end{array}$ & $\begin{array}{l}\text { Foreign } \\
\text { ownership }\end{array}$ \\
\hline $\begin{array}{l}\text { Credit growth (pre- } \\
\text { crisis) }\end{array}$ & 1 & & & & & & & & & & & & \\
\hline Credit drop (crisis) & 0.9268 & 1 & & & & & & & & & & & \\
\hline $\begin{array}{l}\text { Credit growth } \\
\text { (crisis) }\end{array}$ & -0.1494 & -0.507 & 1 & & & & & & & & & & \\
\hline NPLs (crisis) & 0.3896 & 0.3963 & -0.1481 & 1 & & & & & & & & & \\
\hline $\begin{array}{l}\text { Cro present (pre- } \\
\text { crisis) } \\
\text { CRO executive }\end{array}$ & -0.0967 & -0.1482 & 0.1519 & -0.0102 & 1 & & & & & & & & \\
\hline & -0.1253 & -0.1129 & 0.001 & -0.1668 & 0.2485 & 1 & & & & & & & \\
\hline $\begin{array}{l}\text { (pre-crisis) } \\
\text { Risk committee } \\
\text { reports to board }\end{array}$ & 0.0183 & -0.0022 & 0.042 & 0.1244 & 0.176 & -0.0442 & 1 & & & & & & \\
\hline & 0.0429 & 0.0144 & 0.0572 & 0.1706 & 0.1228 & -0.0396 & 0.7899 & 1 & & & & & \\
\hline $\begin{array}{l}\text { crisis) } \\
\text { Board expertise }\end{array}$ & -0.1469 & -0.1143 & -0.0332 & -0.1347 & 0.0274 & -0.0505 & 0.1692 & 0.135 & 1 & & & & \\
\hline $\begin{array}{l}\text { (pre-crisis) } \\
\text { Board }\end{array}$ & 0.1011 & 0.1179 & -0.0709 & -0.0791 & 0.054 & 0.1701 & -0.096 & -0.0765 & -0.0487 & 1 & & & \\
\hline $\begin{array}{l}\text { independence (pre- } \\
\text { crisis) }\end{array}$ & -0.1257 & -0.2056 & 0.2588 & -0.1391 & -0.0184 & 0.0742 & -0.0337 & -0.0109 & 0.0678 & -0.1075 & 1 & & \\
\hline crisis) & 0.0155 & 0.1133 & -0.2613 & -0.1795 & 0.0537 & 0.0811 & -0.0597 & -0.083 & -0.0394 & 0.4599 & -0.2853 & 1 & \\
\hline Foreign ownership & -0.0495 & 0.0313 & -0.1935 & -0.2332 & 0.0768 & 0.0988 & -0.0912 & -0.1506 & 0.079 & 0.3896 & -0.2492 & 0.7216 & 1 \\
\hline
\end{tabular}


Appendix 4a Impact of interaction between risk management and corporate governance and the regulatory framework on credit growth

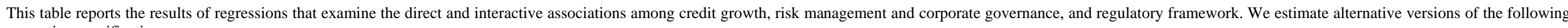
regression specification:

$$
\operatorname{Credgr}_{i, c, 2005-2007}=\alpha_{c}+\beta \times \operatorname{Gov}_{i, 2005-2007}+\gamma \times \operatorname{Gov}_{i, 2005-2007} \times \operatorname{LaxReg}_{j, 2005-2007}+\delta \times \operatorname{Control}_{i, 2005-2007}+\varepsilon_{i, c}
$$

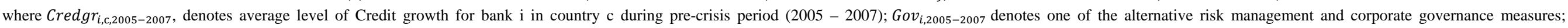

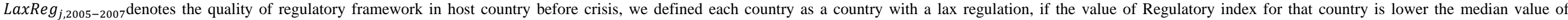

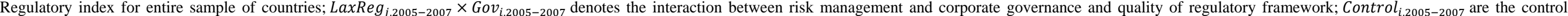

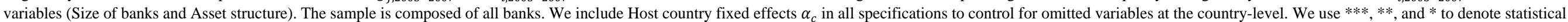
significance at the $1 \%, 5 \%$, and $10 \%$ levels, respectively.

\begin{tabular}{|c|c|c|c|c|c|c|c|c|c|c|c|}
\hline $\begin{array}{l}\text { Dependent: Credit growth (pre- } \\
\text { crisis) }\end{array}$ & CRO present & $\begin{array}{c}\text { CRO } \\
\text { executive }\end{array}$ & $\begin{array}{c}\text { Risk } \\
\text { committee }\end{array}$ & $\begin{array}{c}\text { Risk } \\
\text { committee } \\
\text { reports to } \\
\text { board }\end{array}$ & Board size & $\begin{array}{c}\text { Board } \\
\text { expertise }\end{array}$ & $\begin{array}{c}\text { Board } \\
\text { independence }\end{array}$ & $\begin{array}{l}\text { Board } \\
\text { foreign }\end{array}$ & $\begin{array}{c}\text { Risk } \\
\text { management } \\
\text { index }\end{array}$ & $\begin{array}{l}\text { Supervisory } \\
\text { board index }\end{array}$ & $\begin{array}{l}\text { Foreign } \\
\text { ownership }\end{array}$ \\
\hline Main term & $\begin{array}{l}4.061 \\
(5.15)\end{array}$ & $\begin{array}{l}-0.694 \\
(4.22)\end{array}$ & $\begin{array}{l}-9.827 \\
(8.49)\end{array}$ & $\begin{array}{r}-9.912 \\
(7.66)\end{array}$ & $\begin{array}{l}5.507 \\
(9.22)\end{array}$ & $\begin{array}{r}\text { 33.130 }^{* * *} \\
(14.29)\end{array}$ & $\begin{array}{l}-9.739 \\
(9.34)\end{array}$ & $\begin{array}{r}-7.837 \\
(5.87)\end{array}$ & $\begin{array}{l}-5.744 \\
(9.31)\end{array}$ & $\begin{array}{r}-7.009 \\
(13.83)\end{array}$ & $\begin{array}{l}6.303 \\
(7.09)\end{array}$ \\
\hline $\begin{array}{l}\text { Interaction (Main term *Lax } \\
\text { regulation) }\end{array}$ & $\begin{array}{r}-8.995 \\
(8.14) \\
\end{array}$ & $\begin{array}{r}17.895^{*} \\
(10.29)\end{array}$ & $\begin{array}{r}1.612 \\
(10.86)\end{array}$ & $\begin{array}{r}4.709 \\
(9.27) \\
\end{array}$ & $\begin{array}{r}-8.767 \\
(8.43) \\
\end{array}$ & $\begin{array}{l}-5.467 \\
(12.97)\end{array}$ & $\begin{array}{r}2.913 \\
(28.92) \\
\end{array}$ & $\begin{array}{r}11.269 \\
(12.46)\end{array}$ & $\begin{array}{r}8.975 \\
(16.51)\end{array}$ & $\begin{array}{r}5.258 \\
(19.00)\end{array}$ & $\begin{array}{r}-11.318 \\
(9.89)\end{array}$ \\
\hline Size of bank & $\begin{array}{r}-5.544^{* *} \\
(2.33)\end{array}$ & $\begin{array}{r}-6.380^{* *} \\
(2.46)\end{array}$ & $\begin{array}{r}-5.301^{* *} \\
(2.13)\end{array}$ & $\begin{array}{r}-5.453^{* *} \\
(2.23)\end{array}$ & $\begin{array}{r}-5.842^{* *} \\
(2.19)\end{array}$ & $\begin{array}{r}-6.717 * * \\
(2.58)\end{array}$ & $\begin{array}{r}-5.713^{* *} \\
(2.32)\end{array}$ & $\begin{array}{r}-5.677^{* *} \\
(2.47)\end{array}$ & $\begin{array}{r}-5.594^{* *} \\
(2.31)\end{array}$ & $\begin{array}{r}-5.592^{* *} \\
(2.50)\end{array}$ & $\begin{array}{r}-5.385^{*} \\
(2.54)\end{array}$ \\
\hline Asset structure - Loan/TA & $\begin{array}{r}13.721 \\
(17.34)\end{array}$ & $\begin{array}{r}12.588 \\
(16.03)\end{array}$ & $\begin{array}{r}14.491 \\
(17.10)\end{array}$ & $\begin{array}{r}16.384 \\
(16.77)\end{array}$ & $\begin{array}{r}11.970 \\
(17.59)\end{array}$ & $\begin{array}{r}8.516 \\
(15.37)\end{array}$ & $\begin{array}{l}11.704 \\
(18.38)\end{array}$ & $\begin{array}{r}17.232 \\
(16.68)\end{array}$ & $\begin{array}{r}14.464 \\
(17.02)\end{array}$ & $\begin{array}{l}15.997 \\
(17.57)\end{array}$ & $\begin{array}{l}10.955 \\
(21.64)\end{array}$ \\
\hline Constant & $\begin{array}{r}119.577 * * * \\
(36.34)\end{array}$ & $\begin{array}{r}130.169 * * * \\
(36.52)\end{array}$ & $\begin{array}{r}117.214^{* * * *} \\
(33.27)\end{array}$ & $\begin{array}{r}117.491^{* * * *} \\
(34.31)\end{array}$ & $\begin{array}{r}122.246^{* * * *} \\
(40.19)\end{array}$ & $\begin{array}{r}111.926 * * * \\
(32.18)\end{array}$ & $\begin{array}{r}124.288^{* * * *} \\
(37.72)\end{array}$ & $\begin{array}{r}120.409^{* * * *} \\
(36.51)\end{array}$ & $\begin{array}{r}120.021 * * * \\
(35.48)\end{array}$ & $\begin{array}{r}121.024^{* * * *} \\
(37.28)\end{array}$ & $\begin{array}{r}117.792^{* * *} \\
(39.61)\end{array}$ \\
\hline $\begin{array}{l}\text { Host country FE } \\
\text { Home country FE }\end{array}$ & $\begin{array}{c}\text { YES } \\
\text { NO }\end{array}$ & $\begin{array}{r}\text { YES } \\
\text { NO }\end{array}$ & $\begin{array}{r}\text { YES } \\
\text { NO }\end{array}$ & $\begin{array}{r}\text { YES } \\
\text { NO }\end{array}$ & $\begin{array}{r}\text { YES } \\
\text { NO }\end{array}$ & $\begin{array}{r}\text { YES } \\
\text { NO }\end{array}$ & $\begin{array}{r}\text { YES } \\
\text { NO }\end{array}$ & $\begin{array}{r}\text { YES } \\
\text { NO }\end{array}$ & $\begin{array}{r}\text { YES } \\
\text { NO }\end{array}$ & $\begin{array}{r}\text { YES } \\
\text { NO }\end{array}$ & $\begin{array}{r}\text { YES } \\
\text { NO }\end{array}$ \\
\hline R-squared & 0.115 & 0.164 & 0.131 & 0.129 & 0.064 & 0.180 & 0.156 & 0.135 & 0.138 & 0.138 & 0.103 \\
\hline N. of cases & 156 & 156 & 156 & 156 & 156 & 156 & 156 & 156 & 156 & 156 & 156 \\
\hline Mean of dependent variable & 49.47 & 49.47 & 49.47 & 49.47 & 49.47 & 49.47 & 49.47 & 49.47 & 49.47 & 49.47 & \\
\hline
\end{tabular}


Appendix 4b Impact of interaction between risk management and corporate governance and the regulatory framework on credit drop

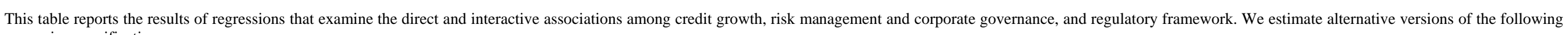
regression specification:

$$
\Delta \operatorname{Credgr}_{i, c}=\alpha_{c}+\beta \times \operatorname{Gov}_{i, 2005-2007}+\gamma \times \operatorname{Gov}_{i, 2005-2007} \times \operatorname{LaxReg}_{j, 2005-2007}+\delta \times \operatorname{Control}_{i, 2005-2007}+\varepsilon_{i, c}
$$

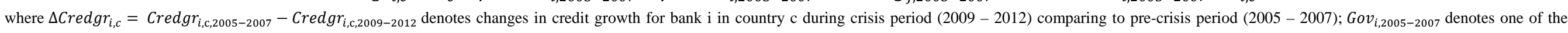

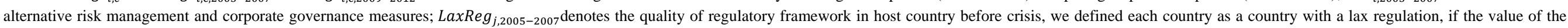

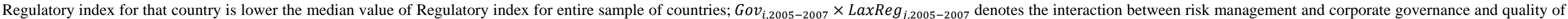

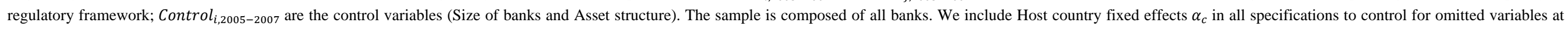
the country-level. We use $* * *, * *$, and * to denote statistical significance at the $1 \%, 5 \%$, and $10 \%$ levels, respectively.

\begin{tabular}{|c|c|c|c|c|c|c|c|c|c|c|c|}
\hline Dependent: Credit drop (crisis) & CRO present & $\begin{array}{c}\text { CRO } \\
\text { executive }\end{array}$ & $\begin{array}{c}\text { Risk } \\
\text { committee }\end{array}$ & $\begin{array}{c}\text { Risk } \\
\text { committee } \\
\text { reports to } \\
\text { board }\end{array}$ & Board size & $\begin{array}{c}\text { Board } \\
\text { expertise }\end{array}$ & $\begin{array}{c}\text { Board } \\
\text { independence }\end{array}$ & $\begin{array}{l}\text { Board } \\
\text { foreign }\end{array}$ & $\begin{array}{c}\text { Risk } \\
\text { management } \\
\text { index }\end{array}$ & $\begin{array}{l}\text { Supervisory } \\
\text { board index }\end{array}$ & $\begin{array}{l}\text { Foreign } \\
\text { ownership }\end{array}$ \\
\hline Main term & $\begin{array}{r}0.291 \\
(4.99)\end{array}$ & $\begin{array}{l}-4.783 \\
(4.89)\end{array}$ & $\begin{array}{r}-10.698 \\
(8.31)\end{array}$ & $\begin{array}{r}-8.948 \\
(5.28)\end{array}$ & $\begin{array}{r}11.998 \\
(11.07)\end{array}$ & $\begin{array}{r}\mathbf{3 3 . 5 8 4} * * \\
(15.81)\end{array}$ & $\begin{array}{l}-18.176 \\
(10.55)\end{array}$ & $\begin{array}{r}-3.512 \\
(8.69)\end{array}$ & $\begin{array}{r}-11.240 \\
(9.13)\end{array}$ & $\begin{array}{l}-2.895 \\
(13.47)\end{array}$ & $\begin{array}{r}11.542 \\
(7.08)\end{array}$ \\
\hline $\begin{array}{l}\text { Interaction (Main term * Lax } \\
\text { regulation) }\end{array}$ & $\begin{array}{l}-9.786 \\
(8.67)\end{array}$ & $\begin{array}{r}\mathbf{2 0 . 2 0 4 *} \\
(11.03)\end{array}$ & $\begin{array}{r}2.961 \\
(14.59)\end{array}$ & $\begin{array}{r}5.641 \\
(13.93)\end{array}$ & $\begin{array}{l}-2.477 \\
(10.61)\end{array}$ & $\begin{array}{r}-8.771 \\
(10.87)\end{array}$ & $\begin{array}{l}-0.775 \\
(29.62)\end{array}$ & $\begin{array}{l}16.687 \\
(15.25)\end{array}$ & $\begin{array}{l}11.493 \\
(20.87)\end{array}$ & $\begin{array}{r}8.428 \\
(19.92)\end{array}$ & $\begin{array}{r}-12.765 \\
(13.48)\end{array}$ \\
\hline Size of bank & $\begin{array}{l}-0.328 \\
(3.08)\end{array}$ & $\begin{array}{r}-1.040 \\
(2.99)\end{array}$ & $\begin{array}{r}-0.219 \\
(2.80)\end{array}$ & $\begin{array}{r}-0.415 \\
(2.91)\end{array}$ & $\begin{array}{r}-1.255 \\
(2.72)\end{array}$ & $\begin{array}{r}-1.562 \\
(3.22)\end{array}$ & $\begin{array}{r}-0.691 \\
(2.92)\end{array}$ & $\begin{array}{r}-1.296 \\
(3.13)\end{array}$ & $\begin{array}{r}-0.324 \\
(3.03)\end{array}$ & $\begin{array}{r}-0.815 \\
(3.04)\end{array}$ & $\begin{array}{r}-0.627 \\
(3.41)\end{array}$ \\
\hline Asset structure - Loan/TA & $\begin{array}{r}37.584^{*} \\
(19.02)\end{array}$ & $\begin{array}{r}35.998^{*} \\
(17.62)\end{array}$ & $\begin{array}{r}38.420^{*} \\
(19.01)\end{array}$ & $\begin{array}{r}40.170 * * \\
(18.83)\end{array}$ & $\begin{array}{r}38.985^{*} \\
(19.84)\end{array}$ & $\begin{array}{r}32.580^{*} \\
(18.44)\end{array}$ & $\begin{array}{r}32.476 \\
(18.80)\end{array}$ & $\begin{array}{r}37.116^{* *} \\
(16.32)\end{array}$ & $\begin{array}{r}38.544^{*} \\
(18.22)\end{array}$ & $\begin{array}{r}39.046^{*} \\
(18.75)\end{array}$ & $\begin{array}{r}30.923 \\
(22.79)\end{array}$ \\
\hline Constant & $\begin{array}{l}29.883 \\
(47.24)\end{array}$ & $\begin{array}{r}36.183 \\
(46.74)\end{array}$ & $\begin{array}{l}25.924 \\
(44.74)\end{array}$ & $\begin{array}{l}26.661 \\
(46.31)\end{array}$ & $\begin{array}{l}18.490 \\
(54.02)\end{array}$ & $\begin{array}{r}20.490 \\
(41.82)\end{array}$ & $\begin{array}{c}37.511 \\
(47.91)\end{array}$ & $\begin{array}{r}37.469 \\
(46.86)\end{array}$ & $\begin{array}{l}27.446 \\
(46.90)\end{array}$ & $\begin{array}{c}31.456 \\
(47.96)\end{array}$ & $\begin{array}{r}30.024 \\
(52.27)\end{array}$ \\
\hline Host country FE & YES & YES & YES & YES & YES & YES & YES & YES & YES & YES & YES \\
\hline Home country FE & NO & NO & NO & NO & NO & NO & NO & NO & NO & NO & NO \\
\hline R-squared & 0.030 & 0.062 & 0.027 & 0.028 & 0.025 & 0.046 & 0.074 & 0.049 & 0.039 & 0.041 & 0.016 \\
\hline N. of cases & 156 & 156 & 156 & 156 & 156 & 156 & 156 & 156 & 156 & 156 & 156 \\
\hline Mean of dependent variable & 43.68 & 43.68 & 43.68 & 43.68 & 43.68 & 43.68 & 43.68 & 43.68 & 43.68 & 43.68 & 43.68 \\
\hline
\end{tabular}


Appendix 4c Impact of interaction between risk management and corporate governance and the regulatory framework on credit growth

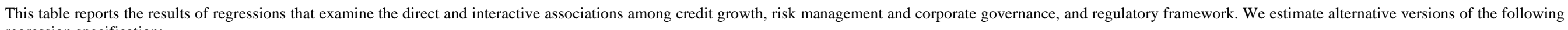
regression specification:

$$
\text { Credgr }_{i, c, 2009-2012}=\alpha_{c}+\beta \times \operatorname{Gov}_{i, 2005-2007}+\gamma \times \operatorname{Gov}_{i, 2005-2007} \times \operatorname{LaxReg}_{j, 2005-2007}+\delta \times \text { Control }_{i, 2005-2007}+\varepsilon_{i, c}
$$

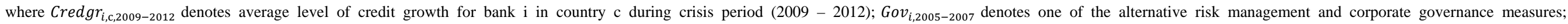

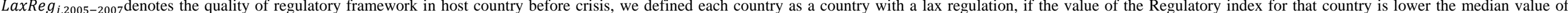

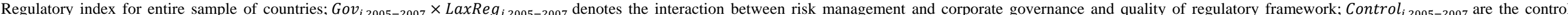

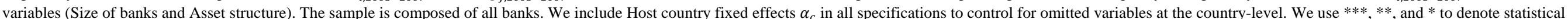
significance at the $1 \%, 5 \%$, and $10 \%$ levels, respectively.

\begin{tabular}{|c|c|c|c|c|c|c|c|c|c|c|c|}
\hline Dependent: Credit growth (crisis) & CRO present & $\begin{array}{c}\text { CRO } \\
\text { executive }\end{array}$ & $\begin{array}{c}\text { Risk } \\
\text { committee }\end{array}$ & $\begin{array}{l}\text { Risk } \\
\text { committee } \\
\text { reports to } \\
\text { board }\end{array}$ & Board size & $\begin{array}{l}\text { Board } \\
\text { expertise }\end{array}$ & $\begin{array}{c}\text { Board } \\
\text { independence }\end{array}$ & $\begin{array}{l}\text { Board } \\
\text { foreign }\end{array}$ & $\begin{array}{c}\text { Risk } \\
\text { management } \\
\text { index }\end{array}$ & $\begin{array}{l}\text { Supervisory } \\
\text { board index }\end{array}$ & $\begin{array}{c}\text { Foreign } \\
\text { ownership }\end{array}$ \\
\hline Main term & $\begin{array}{r}3.572 * * \\
(1.44)\end{array}$ & $\begin{array}{r}\text { 4.258* }^{*} \\
(2.15)\end{array}$ & $\begin{array}{l}1.010 \\
(2.69)\end{array}$ & $\begin{array}{l}-0.978 \\
(2.98)\end{array}$ & $\begin{array}{r}-6.597 * * \\
(3.11)\end{array}$ & $\begin{array}{r}-0.463 \\
(5.15)\end{array}$ & $\begin{array}{r}\text { 8.635* } \\
(4.45)\end{array}$ & $\begin{array}{r}-4.405 \\
(4.57)\end{array}$ & $\begin{aligned} \mathbf{5 . 5 7 4 *} \\
(3.16)\end{aligned}$ & $\begin{array}{l}-4.120 \\
(3.77)\end{array}$ & $\begin{array}{r}-\mathbf{5 . 4 4 2 * *} \\
(2.49)\end{array}$ \\
\hline $\begin{array}{l}\text { Interaction (Main term * Lax } \\
\text { regulation) }\end{array}$ & $\begin{array}{r}-0.951 \\
(7.26)\end{array}$ & $\begin{array}{r}-2.938 \\
(3.45)\end{array}$ & $\begin{array}{r}-1.672 \\
(8.73)\end{array}$ & $\begin{array}{r}-0.648 \\
(10.31)\end{array}$ & $\begin{array}{l}-6.476 \\
(6.63)\end{array}$ & $\begin{array}{l}3.863 \\
(6.78)\end{array}$ & $\begin{array}{r}2.401 \\
(13.32)\end{array}$ & $\begin{array}{r}-4.980 \\
(7.32)\end{array}$ & $\begin{array}{r}-4.031 \\
(11.32)\end{array}$ & $\begin{array}{r}-1.500 \\
(6.44)\end{array}$ & $\begin{array}{l}1.668 \\
(6.80)\end{array}$ \\
\hline Size of bank & $\begin{array}{r}-5.297^{* * * *} \\
(1.19)\end{array}$ & $\begin{array}{r}-5.466^{* * * *} \\
(1.15)\end{array}$ & $\begin{array}{r}-5.224^{* * *} \\
(1.15)\end{array}$ & $\begin{array}{r}-5.180^{* * *} \\
(1.14)\end{array}$ & $\begin{array}{r}-4.707 * * * \\
(1.03)\end{array}$ & $\begin{array}{r}-5.313^{* * *} \\
(1.30)\end{array}$ & $\begin{array}{r}-5.157 * * * \\
(1.07)\end{array}$ & $\begin{array}{r}-4.528^{* * *} \\
(1.19)\end{array}$ & $\begin{array}{r}-5.379 * * * \\
(1.19)\end{array}$ & $\begin{array}{r}-4.971^{* * *} \\
(1.03)\end{array}$ & $\begin{array}{r}-4.892^{* * *} \\
(1.33)\end{array}$ \\
\hline Asset structure - Loan/TA & $\begin{array}{r}-22.352 * * * \\
(6.77)\end{array}$ & $\begin{array}{r}-21.667 * * * \\
(7.24)\end{array}$ & $\begin{array}{r}-22.228 * * * \\
(7.53)\end{array}$ & $\begin{array}{r}-22.099 * * \\
(7.64)\end{array}$ & $\begin{array}{r}-25.492 * * * \\
(6.75)\end{array}$ & $\begin{array}{r}-22.409 * * * \\
(7.50)\end{array}$ & $\begin{array}{r}-19.233^{* *} \\
(6.76)\end{array}$ & $\begin{array}{r}-18.343^{* *} \\
(7.12)\end{array}$ & $\begin{array}{r}-22.384 * * * \\
(7.36)\end{array}$ & $\begin{array}{r}-21.458 * * \\
(7.35)\end{array}$ & $\begin{array}{r}-18.197 * * \\
(6.97)\end{array}$ \\
\hline Constant & $\begin{array}{r}90.841^{* * *} \\
(16.25)\end{array}$ & $\begin{array}{r}94.794 * * * \\
(17.09)\end{array}$ & $\begin{array}{r}92.330^{* * * *} \\
(17.13)\end{array}$ & $\begin{array}{r}91.836^{* * *} \\
(17.31)\end{array}$ & $\begin{array}{r}104.999^{* * *} \\
(21.32)\end{array}$ & $\begin{array}{r}92.473^{* * *} \\
(16.58)\end{array}$ & $\begin{array}{r}87.894^{* * *} \\
(16.30)\end{array}$ & $\begin{array}{r}84.094^{* * * *} \\
(17.02)\end{array}$ & $\begin{array}{r}93.384^{* * *} \\
(17.00)\end{array}$ & $\begin{array}{r}90.963^{* * * *} \\
(16.24)\end{array}$ & $\begin{array}{r}88.724^{* * * *} \\
(18.54)\end{array}$ \\
\hline $\begin{array}{l}\text { Host country FE } \\
\text { Home country FE }\end{array}$ & $\begin{array}{r}\text { YES } \\
\text { NO }\end{array}$ & $\begin{array}{r}\text { YES } \\
\text { NO }\end{array}$ & $\begin{array}{r}\text { YES } \\
\text { NO }\end{array}$ & $\begin{array}{r}\text { YES } \\
\text { NO }\end{array}$ & $\begin{array}{r}\text { YES } \\
\text { NO }\end{array}$ & $\begin{array}{r}\text { YES } \\
\text { NO }\end{array}$ & $\begin{array}{r}\text { YES } \\
\text { NO }\end{array}$ & $\begin{array}{r}\text { YES } \\
\text { NO }\end{array}$ & $\begin{array}{r}\text { YES } \\
\text { NO }\end{array}$ & $\begin{array}{r}\text { YES } \\
\text { NO }\end{array}$ & $\begin{array}{r}\text { YES } \\
\text { NO }\end{array}$ \\
\hline R-squared & 0.184 & 0.179 & 0.177 & 0.177 & 0.080 & 0.187 & 0.200 & 0.184 & 0.175 & 0.164 & 0.185 \\
\hline N. of cases & 156 & 156 & 156 & 156 & 156 & 156 & 156 & 156 & 156 & 156 & 156 \\
\hline Mean of dependent variable & 5.82 & 5.82 & 5.82 & 5.82 & 5.82 & 5.82 & 5.82 & 5.82 & 5.82 & 5.82 & 5.82 \\
\hline
\end{tabular}


Appendix 4d Impact of interaction between risk management and corporate governance and the regulatory framework on credit losses

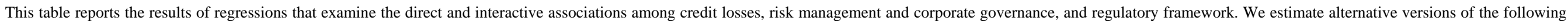
regression specification:

$$
N P L_{i, c, 2009-2012}=\alpha_{c}+\beta \times \operatorname{Gov}_{i, 2005-2007}+\gamma \times \operatorname{Gov}_{i, 2005-2007} \times \operatorname{LaxReg}_{j, 2005-2007}+\delta \times \operatorname{Control}_{i, 2005-2007}+\varepsilon_{i, c}
$$

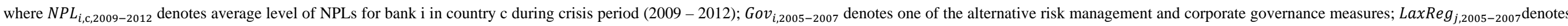

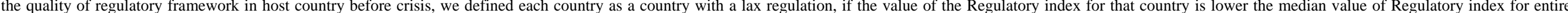

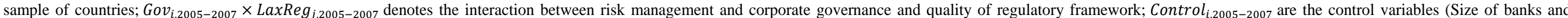

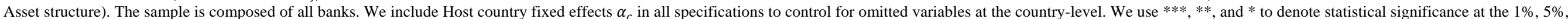
and $10 \%$ levels, respectively.

\begin{tabular}{|c|c|c|c|c|c|c|c|c|c|c|c|}
\hline Dependent: Credit losses (crisis) & CRO present & $\begin{array}{c}\text { CRO } \\
\text { executive }\end{array}$ & $\begin{array}{c}\text { Risk } \\
\text { committee }\end{array}$ & $\begin{array}{l}\text { Risk } \\
\text { committee } \\
\text { reports to } \\
\text { board }\end{array}$ & Board size & $\begin{array}{c}\text { Board } \\
\text { expertise }\end{array}$ & $\begin{array}{c}\text { Board } \\
\text { independence }\end{array}$ & $\begin{array}{l}\text { Board } \\
\text { foreign }\end{array}$ & $\begin{array}{c}\text { Risk } \\
\text { management } \\
\text { index }\end{array}$ & $\begin{array}{l}\text { Supervisory } \\
\text { board index }\end{array}$ & $\begin{array}{l}\text { Foreign } \\
\text { ownership }\end{array}$ \\
\hline Main term & $\begin{array}{l}2.211 \\
(2.49)\end{array}$ & $\begin{array}{r}-2.073 \\
(2.51)\end{array}$ & $\begin{array}{l}0.293 \\
(2.63)\end{array}$ & $\begin{array}{l}2.881 \\
(2.86)\end{array}$ & $\begin{array}{l}2.896 \\
(3.23)\end{array}$ & $\begin{array}{l}3.525 \\
(4.86)\end{array}$ & $\begin{array}{r}-7.310 * * \\
(2.86)\end{array}$ & $\begin{array}{r}-0.983 \\
(3.90)\end{array}$ & $\begin{array}{l}1.661 \\
(4.29)\end{array}$ & $\begin{array}{l}0.746 \\
(2.96)\end{array}$ & $\begin{array}{l}2.833 \\
(2.78)\end{array}$ \\
\hline $\begin{array}{l}\text { Interaction (Main term *Lax } \\
\text { regulation) }\end{array}$ & $\begin{array}{l}1.103 \\
(4.96) \\
\end{array}$ & $\begin{array}{r}-0.160 \\
(2.98)\end{array}$ & $\begin{array}{r}7.652 \\
(4.86) \\
\end{array}$ & $\begin{array}{l}6.744 \\
(5.27) \\
\end{array}$ & $\begin{array}{l}1.307 \\
(4.68) \\
\end{array}$ & $\begin{array}{r}-9.342 \\
(5.83) \\
\end{array}$ & $\begin{array}{r}13.195 \\
(13.75) \\
\end{array}$ & $\begin{array}{r}-7.920^{*} \\
(4.40)\end{array}$ & $\begin{array}{l}6.626 \\
(5.74) \\
\end{array}$ & $\begin{array}{r}-12.756^{* *} \\
(4.60) \\
\end{array}$ & $\begin{array}{r}-8.246^{* *} \\
(3.42)\end{array}$ \\
\hline Size of bank & $\begin{array}{r}-1.718^{*} \\
(0.85)\end{array}$ & $\begin{array}{r}-1.409 \\
(0.87)\end{array}$ & $\begin{array}{r}-1.671^{*} \\
(0.86)\end{array}$ & $\begin{array}{r}-1.656^{*} \\
(0.85)\end{array}$ & $\begin{array}{r}-1.789 * * \\
(0.75)\end{array}$ & $\begin{array}{r}-1.528^{*} \\
(0.80)\end{array}$ & $\begin{array}{r}-1.653^{* *} \\
(0.78)\end{array}$ & $\begin{array}{r}-1.122 \\
(0.71)\end{array}$ & $\begin{array}{r}-1.825^{*} \\
(0.90)\end{array}$ & $\begin{array}{r}-1.244 \\
(0.79)\end{array}$ & $\begin{array}{r}-1.335 \\
(0.80)\end{array}$ \\
\hline Asset structure - Loan/TA & $\begin{array}{r}-6.270 \\
(8.13)\end{array}$ & $\begin{array}{l}-6.549 \\
(7.56)\end{array}$ & $\begin{array}{l}-6.879 \\
(7.01)\end{array}$ & $\begin{array}{l}-7.252 \\
(6.99)\end{array}$ & $\begin{array}{r}-5.404 \\
(6.45) \\
\end{array}$ & $\begin{array}{l}-7.597 \\
(7.68)\end{array}$ & $\begin{array}{r}-7.165 \\
(7.65) \\
\end{array}$ & $\begin{array}{l}-4.297 \\
(6.56)\end{array}$ & $\begin{array}{l}-6.277 \\
(7.53)\end{array}$ & $\begin{array}{l}-6.927 \\
(7.47)\end{array}$ & $\begin{array}{r}-7.856 \\
(7.56)\end{array}$ \\
\hline Constant & $\begin{array}{r}40.173^{* * *} \\
(12.33) \\
\end{array}$ & $\begin{array}{r}38.750^{* * *} \\
(12.99) \\
\end{array}$ & $\begin{array}{r}41.162^{* * *} \\
(13.18) \\
\end{array}$ & $\begin{array}{r}41.186^{* * *} \\
(13.06) \\
\end{array}$ & $\begin{array}{r}36.526^{* *} \\
(14.21) \\
\end{array}$ & $\begin{array}{r}41.157^{* * *} \\
(11.99) \\
\end{array}$ & $\begin{array}{r}42.126^{* * *} \\
(11.87) \\
\end{array}$ & $\begin{array}{r}35.457^{* * *} \\
(10.81) \\
\end{array}$ & $\begin{array}{r}42.283^{* * *} \\
(13.63) \\
\end{array}$ & $\begin{array}{r}38.955^{* * *} \\
(11.96) \\
\end{array}$ & $\begin{array}{r}38.413^{* * *} \\
(12.07) \\
\end{array}$ \\
\hline $\begin{array}{l}\text { Host country FE } \\
\text { Home country FE }\end{array}$ & $\begin{array}{r}\text { YES } \\
\text { NO }\end{array}$ & $\begin{array}{r}\text { YES } \\
\text { NO }\end{array}$ & $\begin{array}{r}\text { YES } \\
\text { NO }\end{array}$ & $\begin{array}{r}\text { YES } \\
\text { NO }\end{array}$ & $\begin{array}{r}\text { YES } \\
\text { NO }\end{array}$ & $\begin{array}{r}\text { YES } \\
\text { NO }\end{array}$ & $\begin{array}{r}\text { YES } \\
\text { NO }\end{array}$ & $\begin{array}{r}\text { YES } \\
\text { NO }\end{array}$ & $\begin{array}{r}\text { YES } \\
\text { NO }\end{array}$ & $\begin{array}{r}\text { YES } \\
\text { NO }\end{array}$ & $\begin{array}{r}\text { YES } \\
\text { NO }\end{array}$ \\
\hline R-squared & 0.063 & 0.060 & 0.073 & 0.067 & 0.046 & 0.000 & 0.049 & 0.027 & 0.071 & 0.015 & 0.017 \\
\hline N. of cases & 156 & 156 & 156 & 156 & 156 & 156 & 156 & 156 & 156 & 156 & 156 \\
\hline Mean of dependent variable & 14.34 & 14.34 & 14.34 & 14.34 & 14.34 & 14.34 & 14.34 & 14.34 & 14.34 & 14.34 & 14.34 \\
\hline
\end{tabular}

